\title{
بعض مظاهر الفاقد الكمي بأعمال الامتحانات في صفوف النقل بالحلقة \\ الثانية من التعليم الاساسى ومتطلبات مواجهتئها \\ "دراسة ميدانية بمحافظة الدقهلية "
}

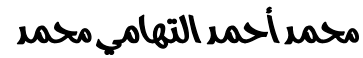

مقدمة

وتتمنل أهم جو انب الإنفاق التعليمسي

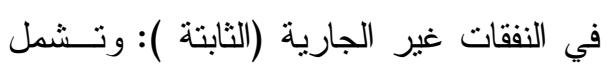

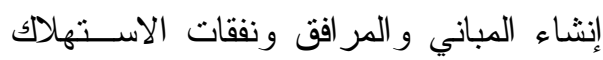

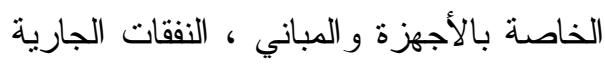

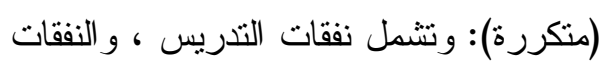

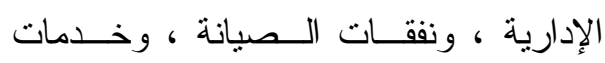

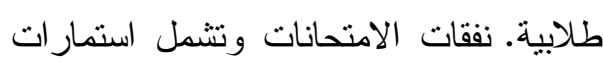
(كر اسات) الإجابات للمو اد الدراسية المختلفة

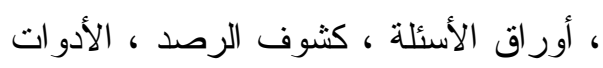

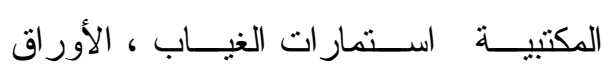

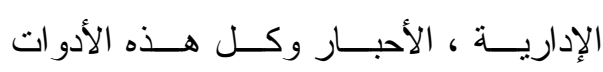

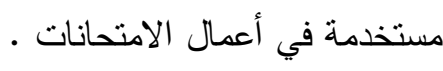

إنَّ الهدر التعليمي أيَّا كان نوعه يؤدى

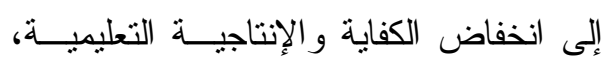
ويترتب على نقص حجم المخرجات (النواتج التعليمية) ، مما يؤدى ذلك إلى تبديد الكثيــر من الجهود البشرية المبذولة في نظم التعليم. وحيث أن نفقات الامتحانات تستحوذ على قدر ليس بالقليل من النفقات المتكـــررة

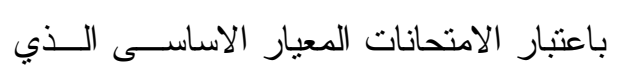

مع الاعتر اف الواسع بأهمية التعلــيم

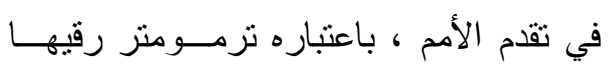

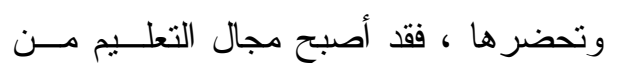
مجالات الدر اسة و الاهتمام في تخطيط التتمية

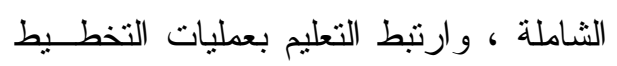

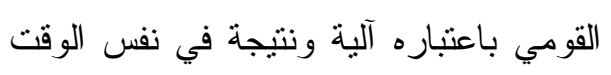

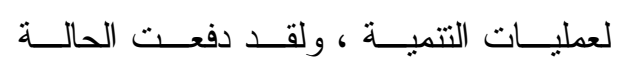

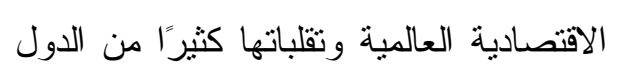

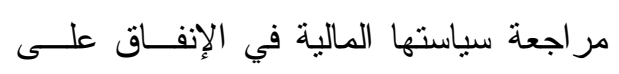

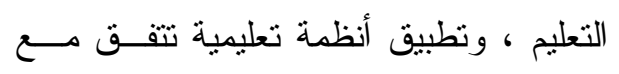

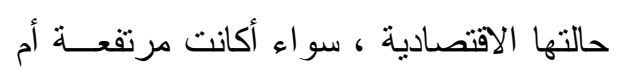

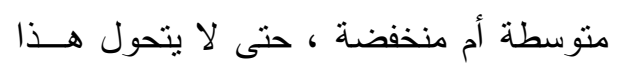

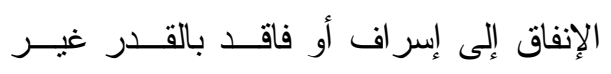

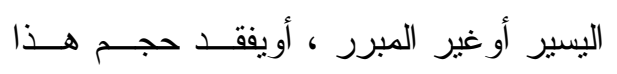

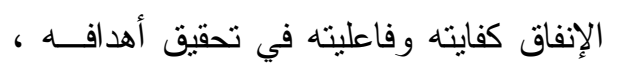

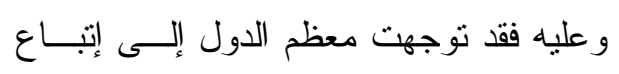

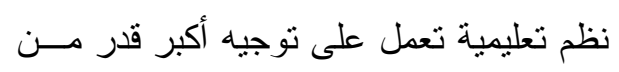

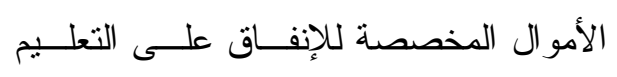

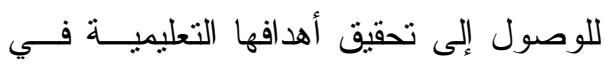

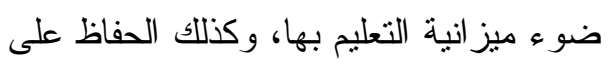
نوعية التعليم وجودة مخرجاته. 
ومشاعر هم فهي بذلك الدكتانور الذي يخضع

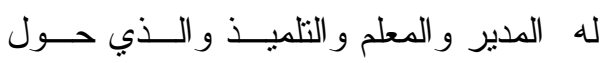

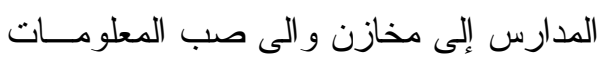

في أذهان التلاميذ بالصورة التي تمكنهم من

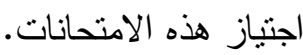

لقد جعـــت الامتحانــات المدرســة

بإمكاناتها البشرية و المادية أن تكون أداة لها

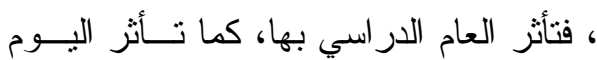
الدراسي ، فقد يسود النظام في أوائل العـام الدر اسي حتى إذا اقتربت بشائر الامتحانــات

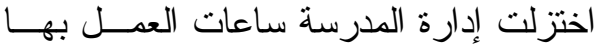
وكثر تغيب التلاميذ عن المدرسة،وقل جهدهم وجهد المدرسين داخل الفصل وكثر خارجها.

"ويبدو الجدل كثير ا بين رجال التربية

و علم النفس حول أهمية الامتحانات ، وحول

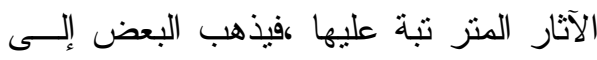

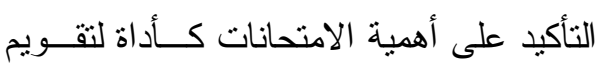

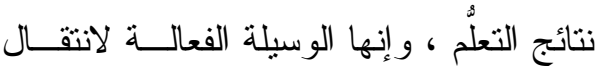

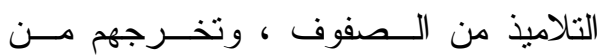

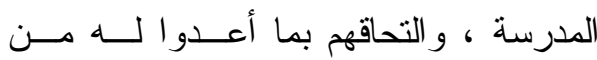

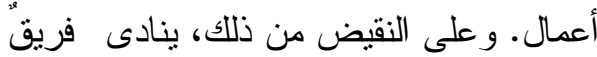
من التزبويين بإلغاء الامتحانات، خــصوصا في المراحل الأولى من التعليم، لما لها مــن الهن

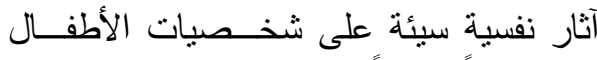

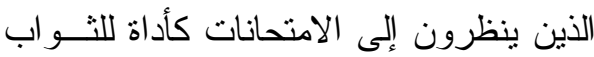
و العقاب ، ويعتبرونها غايـــة فــي ذاتهــــا ،

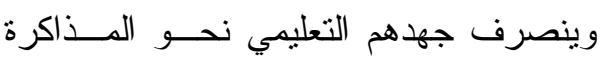

يكثف عما وصلت إليه الجهود في العمليــة التعليمية من نجاح و إخفاق. و الامتحانات ينظر إليها علــى أنهـــا

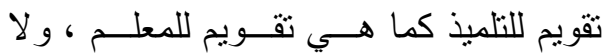
غر ابة في ذلك ما دامت نسبة الناجحين فـي نظر الناس هي دلالة النجاح فــي المهنــة ،

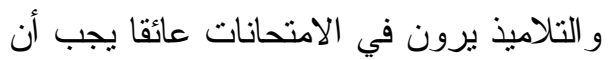
يتخطاه الفرد لينال النجاح. وبـــلك أصــبح

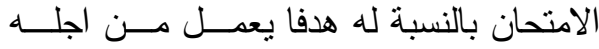

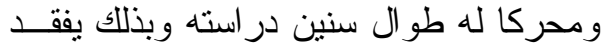
التعليم كل ما له قيمة من عناصره ، و ويصبح

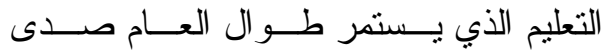

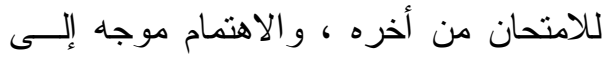
إعداد التلميذ للامتحان بدلا من إعداده للحياة ، والامتحانات بنظامها الحالى تدعو التلاميذ إلى الاهنمام المبكر بالتعليم باعتباره وســيلة

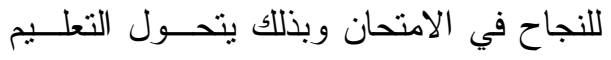
فيصبح جزءًا من عملية الامتحان بدلا من أن الن

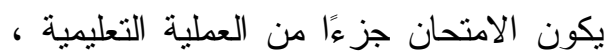
لان الامتحان يلعب دورا هاما في مسستقبله الدراسي. ومن هنا نلمس القلق المستمر الذي لإني

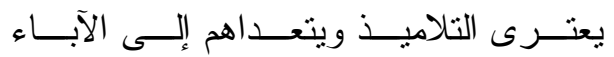

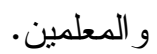
وعلى هذا فقد أصبحت الامتحانــات المدرسية في نظر جميع المنصلين بالعمليـــة

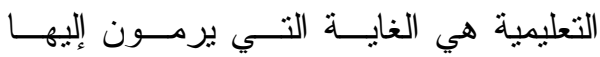

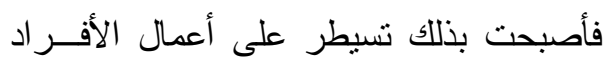




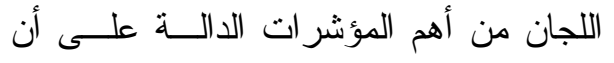
إدارة المؤسسة التعليمية تستخدم منهجاً علمياً تربوياً في إدارتها للمؤسسة التعليمية. "إن من أهم العمليات التزبوية تقـــيم

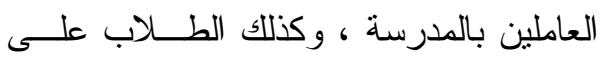

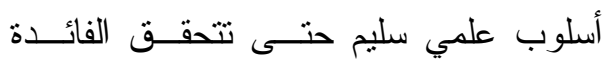
المرجوة من العملية التعليمية بحيث لا يكون

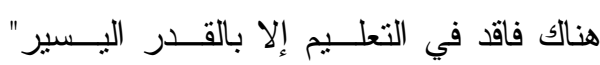

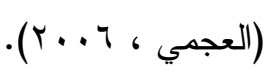

وحيث أن مشكلات أعمال الامتحانات كثيرة ومنها الفاقد في الأوراق المستخدمة في

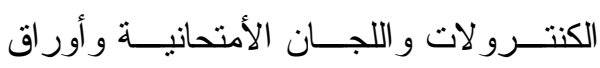

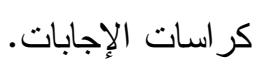

\section{وعلى ضوء ما سبق، يمكن تحديا مشكلة} الاراسة الحالية في التساؤل الرئيس التالي: ما أهم مشكلات أعمال الامتحانات في صفوف النقل بالحلقة الثانيــة مــن التعلــيم الاساسى؟ وسبل مو اجهتها؟ وتتفرع منه الأسئلة التالية: 1- ما أهم مظاهر الفاقد الكـــي بأعمــال الامتحانات في صفوف النقل بالحلقـــة دهـة

$$
\text { الثانية من التعليم الاساسى؟ }
$$

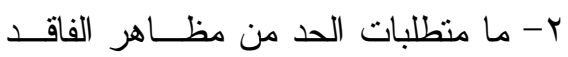

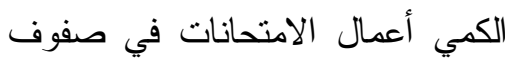
النقل بالحلقــة الثانيــة مــن التعلــيم

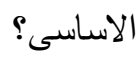

للامتحان فيلجأ ون إلى الحفظ و الاســتظهار ،

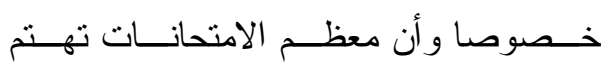
بجو انب الحفظ و الاختزان و الاسترجاع" (عبد الدوان

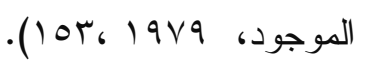
مشكلة البحث :

باســتقر اء المعــايير و المؤثــــــات و الممارسات للمجالات الفرعية المنبتقة مسن بـن المجالين الرئيسين القدرة المؤسسية الفاعليـــة التعليمية للهيئة القومية للاعتماد و الجودة في لئنين مصر وهي الجهة الوحيدة التي لها حق منح

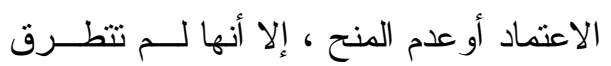

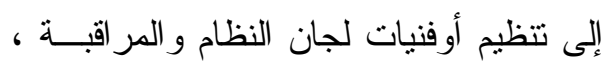
المكلفة بشئون إدارة الكنترو لات و الامتحانات لثنات

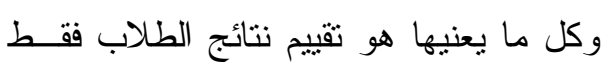

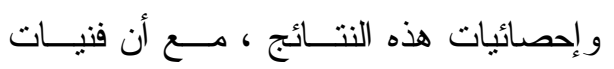

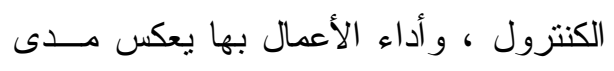

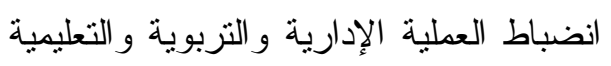

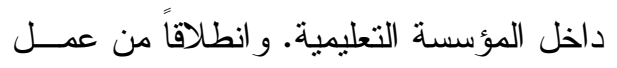

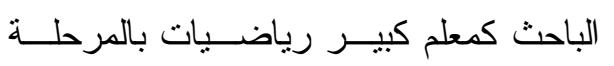

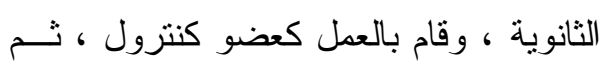
برئاسة كنترول إحدى مدارس الحلقة الثانيــة

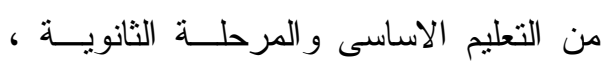

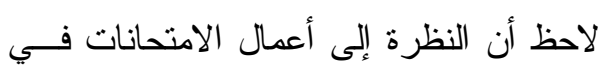

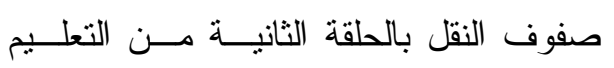

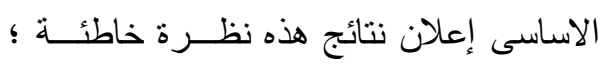

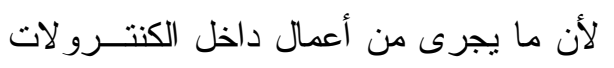

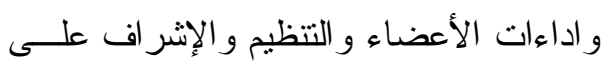


وتطوير ها. وبالرغم مـن هـــــ الوظــائف

المنوط بها إلا أن الفاقد المادي و الذي يتوغل

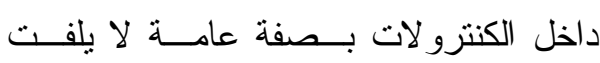

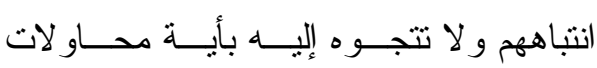

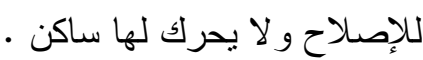

أهمية الموضوع ذاته تأتى من انــهـ

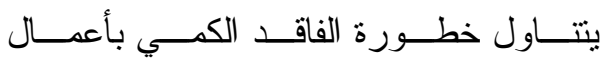
الامتحانات فى صفوف النقل بالحلقة الثانيـــة من التعليم الاساسى ، وسبل مو اجهته وقطاع المستفيدين من هذا البحث ومنهم: أ- المخططــــون وواضـــعو الــسياسات التعليمية للتعليم قبل الجامعي.

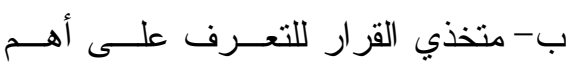

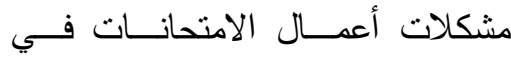
صفوف النقل بالحلقة الثانية من التعليم الاساسى.

ت- القائمين على الهيئة القومية للاعتمــاد

$$
\text { و الجودة ومر اجعو ها. }
$$

ث- العاملين و الإداريين و المسئولين عـن

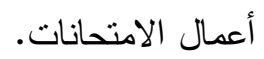

ج- الطالب وما يعود عليه نتيجة الحــد

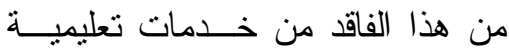
متعددة.

ح- قد يسهم هذا البحث في أثراء المكتبة

$$
\text { التزبوية . }
$$

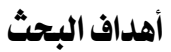

يتمنل الهذف الرئيسي فـي تحديــد

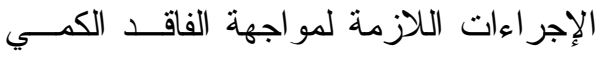

بأعمال الامتحانات في صفوف النقل بالحلقة الثانية من التعليم الاساسى وذللك من خلال:

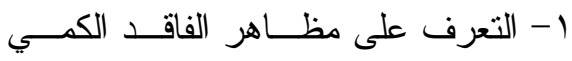

باعمال الامتحانات فى صفوف النقــلـ بالحلقة الثانية من التعليم الاساسى. ץ- متطلبات الحد من مظاهر الفاقد الكمي بأعمال الامتحانات في صفوف النقــلــل بالحلقة الثانية من التعليم الاساسى r- تقديم عدد من المقترحات التـي مـن شأنها مو اجهة هذه المشكلة.

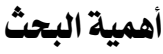

تتضح أهمية مشكلة البحث الحالي في

النقاط الآتية لجان النظام والمر اقبة هي جزء هام من النظام التعليمي ليس لأنها المــسئولة عن إدارة شئون الامتحانات ، فحسب بل في لهن لهن ضوء نتائجها يتم تقويم الطالب من الناحيــة التحصيلية وانتقاله من صف إلى صف أعلى نك ، وتقويم المناهج و الكتب المدرسية ، وتقويم أعمال الريادة و المجالس المدرسية المختلفة ، وتقويم إمكانيات المدرسة المادية و البشرية ،

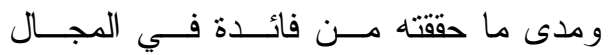

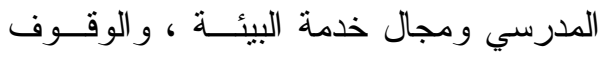

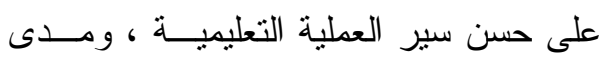
تحقيقها لأهدافها ،ومدى نجاح جهود تحسينها 


\section{أدوات البحث}

استبانه مظاهر الفاقد الكمي بأعهــال

الامتحانات فى صفوف النقل بمدارس الحلقة

الثانية من التعليم الاساسى.

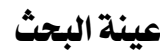

تم تطبيق أدوات البحث علــى عينــة

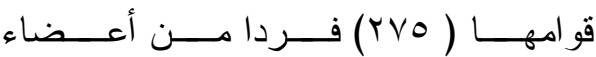

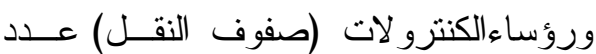

(00) مدرسة من مدارس الحلقة الثانية مـن

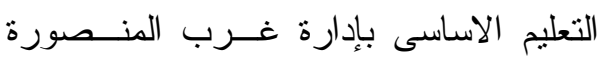

وإدارة السنبلاوين وإدارة العنزلة كونهم من الفنان

الجهات المحدة لهذه المشكلات والمسـتفيدة

من هذا البحث.

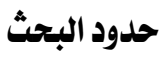

الحدود الجغرافية : مدارس الحلقــة

الثانية من التعليم الاساسى (صفوف النقــلـ)

بمحافظة الدقهلية.

الحدودالبشرية : رؤســاء وأعـضـاء

كنترو لات (صفوف النقل) بالحلقة الثانية من

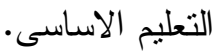

الحدود الزمنيــة : العـام الدراسـى

$r \cdot 19-r \cdot 11$

الداسات السابقة

أولا : دراسات عربية

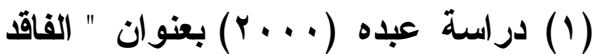

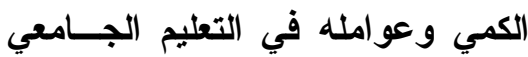

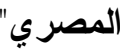

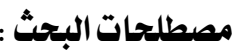

أعمال الامتحانات : نلك الإجراءات

و التدابير التي تتخذها المؤسسة التعليمية قبل

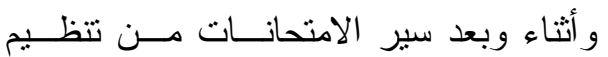

وترقيم و الإثراف والمر اقبة و التأمين اللجان الأمتحانية ، وتتفيذ التعليمات الخاصة

بالامتحانات ، و التـصحيح ورصـــ

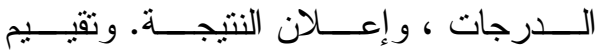

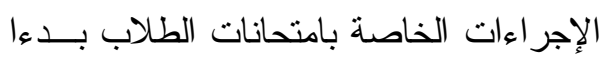
بالمدخلات و انتهاء بالنو اتج. الحلقة الثانية من التعليم الاساسى:

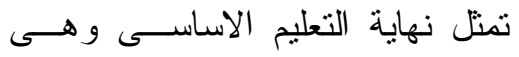

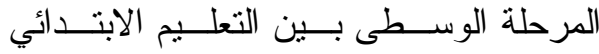

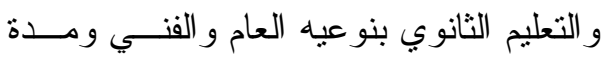

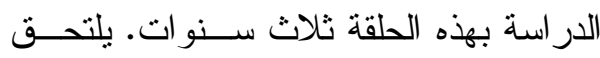
بهذه الحلقة التلميذ بعد حصوله على شـهـادة إتمام الدر اسة الابتدائية.

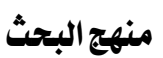
وفقا لطبيعة البحث و أهدافه اســتخدم

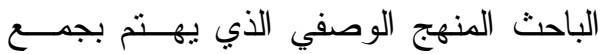

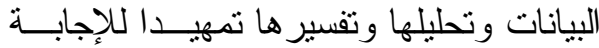
عن تساؤلات البحث بدقة ،ثم القيام بالدر اسة

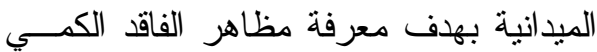
باعمال الامتحانات في صفوف النقل بالحلقة الثانية من التعليم الاساسى وسبل مو اجهتهـا وذلك باستخدام أدو ات احصائية مناسبة. 


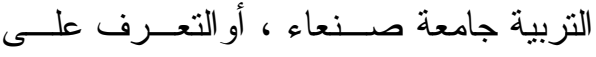

$$
\begin{aligned}
& \text { هدفت الدراسة إلى الإقلال من الفقــــ } \\
& \text { العلاقة بين عو امل الهدر التربوي وبعـضهاء التها }
\end{aligned}
$$

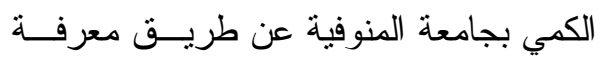

$$
\begin{aligned}
& \text { الــبعض ، و اعتمــدت الدر اســـة علــى أداة }
\end{aligned}
$$

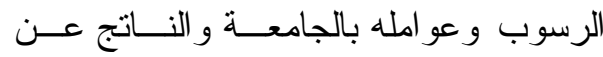

$$
\begin{aligned}
& \text { الاستبانه لجمع البيانات ومن ثم معالجة هــــه } \\
& \text { تدفقهم من فرقة إلى أخرى داخل كــل كليــــة }
\end{aligned}
$$

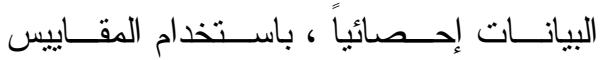

$$
\begin{aligned}
& \text { من كليات الجامعة ومعرفة النسب المئويــة }
\end{aligned}
$$

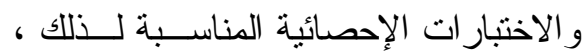

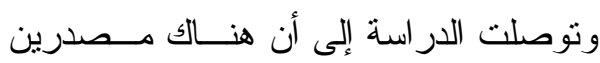

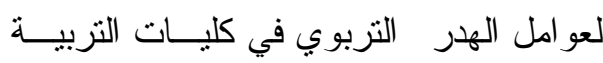

$$
\begin{aligned}
& \text { جامعة صنعاء هما. } \\
& \text { البيئــة الخارجيــة وتــشمل عو امسـلـ } \\
& \text { مرتبطة بالطالب نفسه، وعو امــل مرتبطــــة }
\end{aligned}
$$

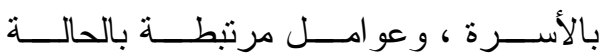

$$
\begin{aligned}
& \text { الاجتماعية و الاقتـــــادية. البيئـــة الداخليـــة }
\end{aligned}
$$

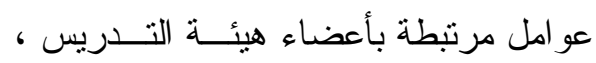

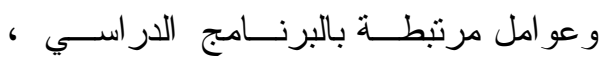

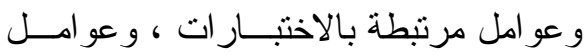

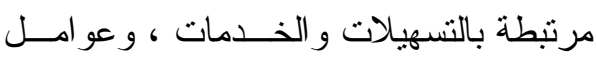

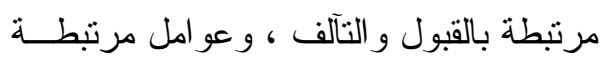

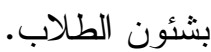

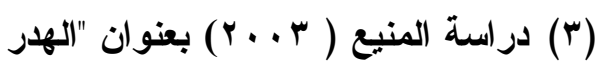

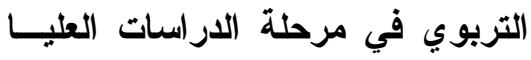

$$
\begin{aligned}
& \text { بكلية البنات التابعة لـــوزارة التربيــة فئة } \\
& \text { والتعليم " لإله } \\
& \text { هدفت الدر اسة إلى وضع إستر اتيجية }
\end{aligned}
$$

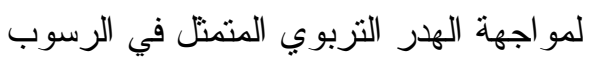

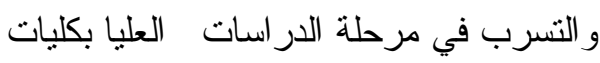

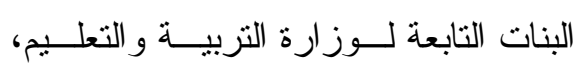

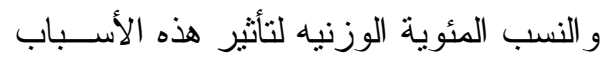

$$
\begin{aligned}
& \text { وتلك العوامل على عملية الرسوب بالجامعة }
\end{aligned}
$$

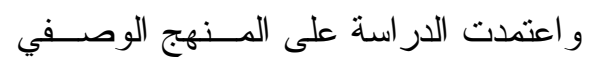

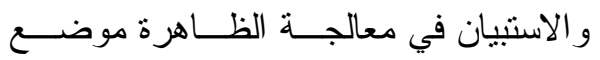

$$
\begin{aligned}
& \text { الار اسة. و وتوصلت الدر اسة إلــى أن تــأثنير }
\end{aligned}
$$

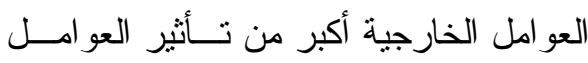

$$
\begin{aligned}
& \text { الداخلية على عملية الرسوب. وجود فــروق }
\end{aligned}
$$

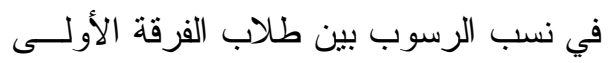

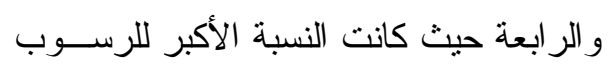

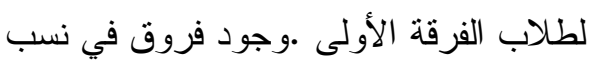

$$
\begin{aligned}
& \text { الرسوب بين طلاب الكليات العملية و النظرية } \\
& \text { حيث كانت النسبة الأكبر للرســوب لــــالح }
\end{aligned}
$$

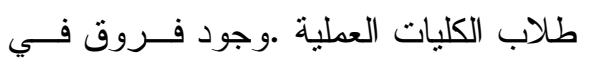

$$
\begin{aligned}
& \text { نسب الرسوب بــين الطـــلاب المنتظمــين } \\
& \text { و المنتسبين. حيـــث كانـــت النــسبة الأكبــر } \\
& \text { للرسوب لصالح الطلاب المنتسبين. }
\end{aligned}
$$

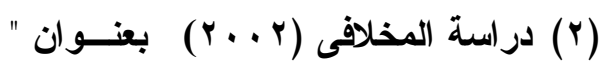

$$
\begin{aligned}
& \text { عوامل الهـر التربــوي فــي التعلـيم }
\end{aligned}
$$

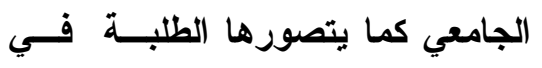

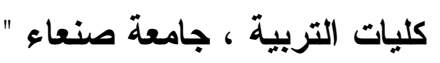

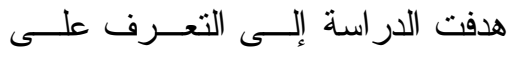

$$
\begin{aligned}
& \text { العو امل المسئولة عن الهدر التربوي بكليات التركي }
\end{aligned}
$$


و اعتمدت الدراسة علــى المــنهج الوصــفي

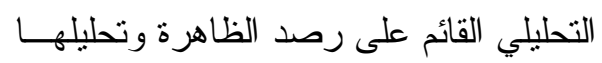

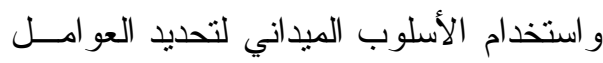
المسبية للهدر الكمي و الكيفي بهدف عــلاج العو امل مستقبلا. و استخدمت الدر اســـة أداة الاستبيان للتعرف علــى العو امــل المــسبية للهرر الكمي و الكيفي في ضو ء بعض معايير

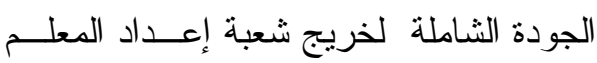

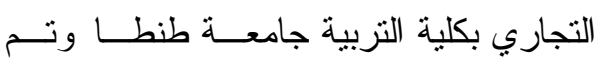
تطبيق الاستبيان على عينة من طلاب شعبة

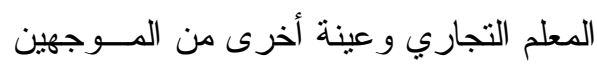
و المديرين. وتوصلت الدر اسة إلى وجود هدر

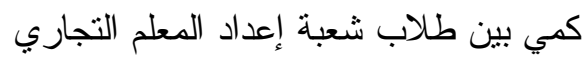

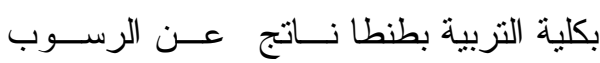
و التسرب للفوج الدر اسي الذي تمت در استه

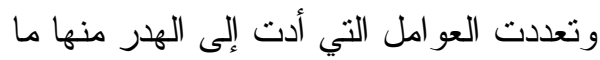

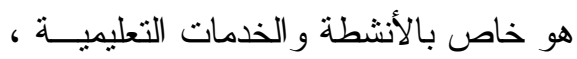
التقويم و الامتحانات و المقرر ات الدر اسية.

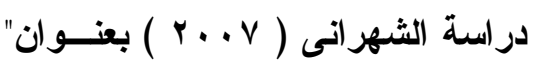
واقع الفاقد التعليمي في بعض كليــات جامعة الملك خالد "

هدفت الدر ساة إلى مناقـشة مفهــوم الفاقد التعليمي في المرحلة الجامعية وجو انبه

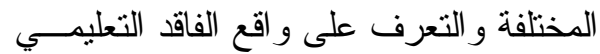

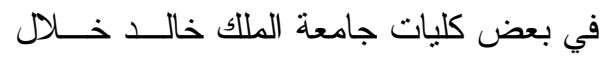

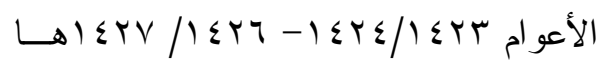

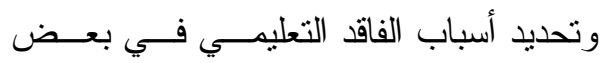

و اعتمدت الدر اسة على أكثر من أداة تمثلـــت

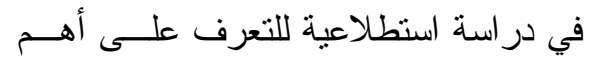
المشكلات و العقبات التي تؤدى إلى ظـــاهرة

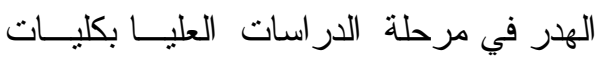
البنات، و استبانه مقدمة إلى عينة من أعضاء هيئة التدريس بكليات البنات لاستطلاع وجهة ولئه

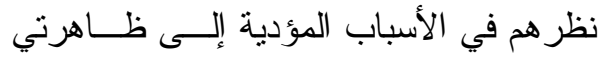

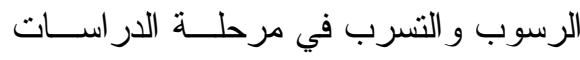

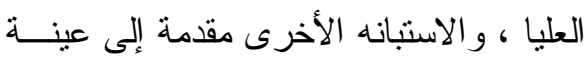

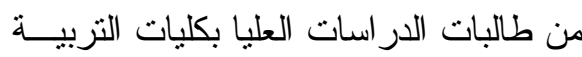
للبنات لاستطلاع ر أيهن في الأسباب المؤدية

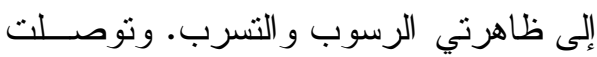

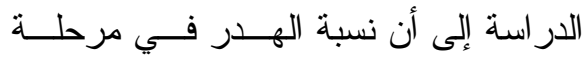

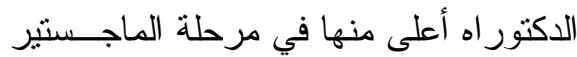

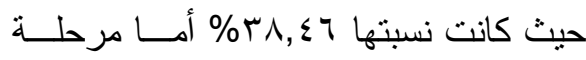

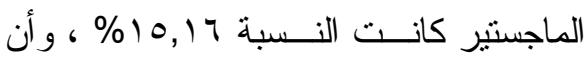
هناك كثير مــن الأســباب ور اء الرســوب

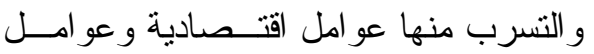
اجتماعية وعو امل نفسية.

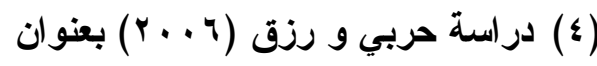

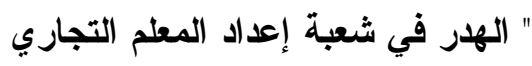

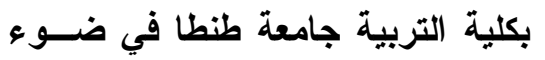
معايير الجودة الثاملة " لكله هدفت الدر اسة إلـىى الكـشف عـن جو انب الهدر التربوي بشعبة المعلم التجاري بكلية التربية جامعة طنطا وتقديم المقترحات و الإجر اءات التي من شأنها علاج المـشكلة. 
موجهتين إلي أعضـاء هيئة التدريس وطلبــة الدر اسـات العليا بـسـت كليــات ( الزر اعــة و الـــصبدلة و التجــــارة و الحقـــوق و التربيــــة و التربية الرياضية). وتوصلت الدر اسة إلـي عدة نتائج أهمها جمود بــر امج الدراســـات العليا فهي تتطلب إعادة تقيـيم موضــوعي شامل لبر امج الدر اسـات العليــا مسـن حيـــث المضمون و العائد الاقتصـادي و المهني منهـــا ارتفاع نسبة الهدر نتيجة عدم حصول طلاب الماجستير و الدكتور اه على الدرجة العلمية -

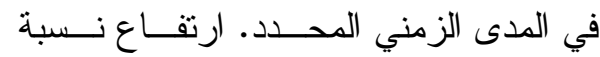
الرسوب و التسرب في درجة الدبلوم المعادل لارجة الماجستير في كلية الحقوق. (V) دراسة الخــولى ( الطلب الاجتماعي على أنماط التعلــيم

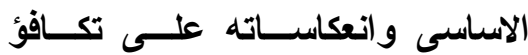
الفرص التعليمية"

هدفت الدراسة إلى محاولـــة إيجــاد صيغة موحدة للتعليم الاساسى ( الالز امــى) يرضى جميع فئات المجتمع ويحقق مطالبهم

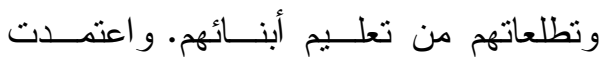
الدر اسة علي المــنـهج التــاريخي و المــنـهج الوصفي. واستخدمت الدراسة استبيان موجه إلى عينة من المديرين و المعلمــين و أوليـــاء الأمور • ونتاولت الدر اسة فصل كامل عـن مئن المشكلات التي تواجه التعليم الاساسى ومنها

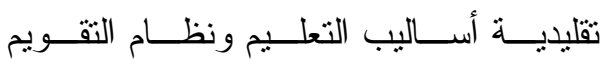

كليات جامعة الملك خالا ، و اقتر اح بعــض الأساليب و الطرق لمعالجتها ، و التوصل إلى أسلوب يمكن من خلاله التتبؤ بالفاقد التعليمي الكمي و الكيفي من خـــله أعـــداد الطــلاب المقبولين في بعض كليات جامعة الملك خالد

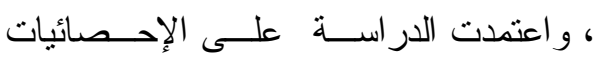
الرسمية التي وفرتها عمادة القبول و التسجيل بالجامعة مباشرة ، و أدلة الخــريجين التــي تعدها العمادة كل عام لحساب الفاقد الكمــي و الكيفي. وتوصلت الدر اسة إلى ارتفاع الفاقد

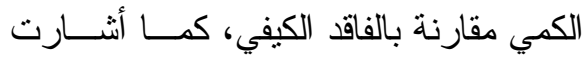
أيضناً إلى أن أعلى نسبة فاقد كــي وكيفـي و اضحة في كلية العلوم بينما تساوت تقريـاً في بقية الكليات عينة الدر اسة .

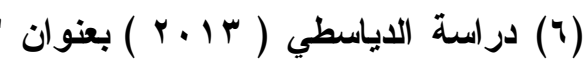
متطلبات الحـ مــن الهـــدر التعليمــي بالار اسات العليا بجامعة المنصورة " هدفت الدراسة الـي التعــرف علـي منظومة الدر اسات العليا بصفة عامه وو اقعها في جامعة المنصورة وتحديد مظاهر الهــدر التعليمي الكمية و الكيفيــة بــبعض كلبــات

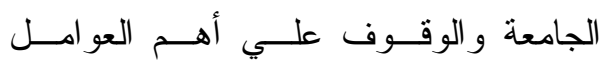
و الأسباب المؤدية لمظاهر الهذر التعليمي في مرحلة الدر اسات العليا بالجامعـــة ومحاولــــة التعرف علي أهم المتطلبات اللازمة للحد من تلك الظاهرة و اعتمدت الدراسة علي المــنهج الوصفي و اســتخدمت الدر اســـة اســتبيانتين 


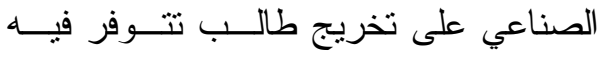

$$
\begin{aligned}
& \text { و الامتحانات و الهار التعليمي ونقص الموارد } \\
& \text { الامكانيات المهنية التي يتطلبها سوق العدــل }
\end{aligned}
$$

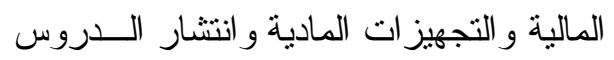

$$
\begin{aligned}
& \text { و الهدر في الكتاب المدرسي وتأخر توزيعه. }
\end{aligned}
$$

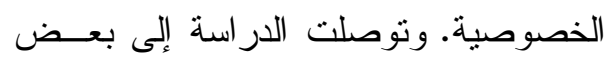

$$
\begin{aligned}
& \text { ثانياً: دراسات أجنبية }
\end{aligned}
$$

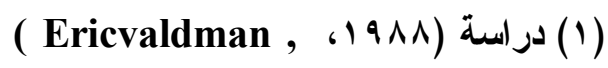

$$
\begin{aligned}
& \text { Swanson }
\end{aligned}
$$

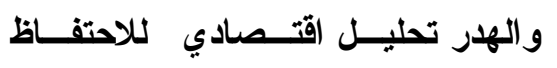

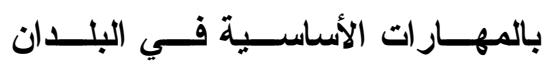

$$
\begin{aligned}
& \text { النامية". } \\
& \text { هدفت الدر اسة إلــى دراســة الــنظم }
\end{aligned}
$$

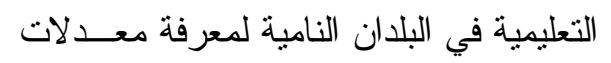

$$
\begin{aligned}
& \text { التسرب و الرسوب و آثار هما فـــي الاحتفـــاظ } \\
& \text { بالمهار ات الأساسية عند الطلاب ، و واعتمدت الترات } \\
& \text { الار اسة على عينة من الطلاب المقيدين فـي الطي }
\end{aligned}
$$

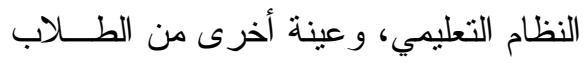

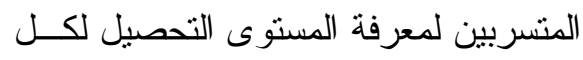

$$
\begin{aligned}
& \text { منهما وتوصلت الدراسة إلى: }
\end{aligned}
$$

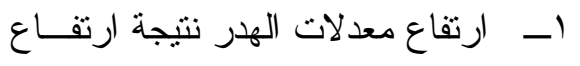

$$
\begin{aligned}
& \text { معدلات الرســوب و التـسرب بــين } \\
& \text { الطلاب. } \\
& \text { r- - جميع المتسربين من النظام التعليمسي }
\end{aligned}
$$

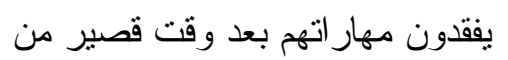

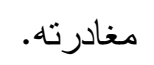

$$
\begin{aligned}
& \text { بــــابد من دراسة الأسباب التي تــؤدي }
\end{aligned}
$$

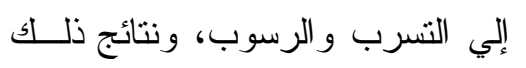

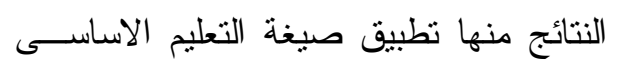

$$
\begin{aligned}
& \text { بمصر بمعناها الصحيح يساعد على تجــاوز } \\
& \text { بعض مشكلات التعليم التقليدي كغلبة الطابع }
\end{aligned}
$$

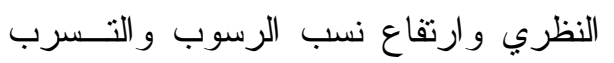

$$
\begin{aligned}
& \text { وتمويل التعليم الاساسى مسئولية الدولة. }
\end{aligned}
$$

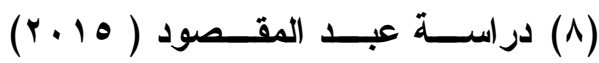

$$
\begin{aligned}
& \text { بعنوان" متطلبات مواجهة بعض عوامل }
\end{aligned}
$$

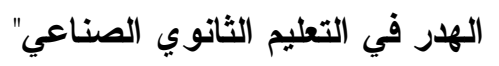

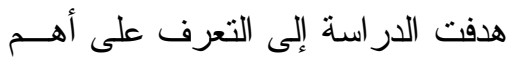

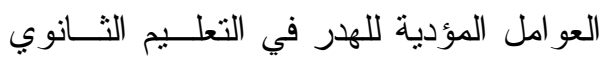

$$
\begin{aligned}
& \text { الصناعي من خـــلال (التــسرب- الغيــاب) } \\
& \text { و عدم التوازن بين مخرجاته وبين منطلبــات }
\end{aligned}
$$

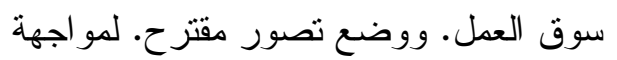

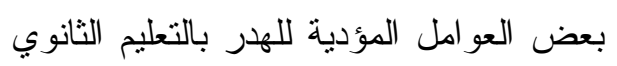

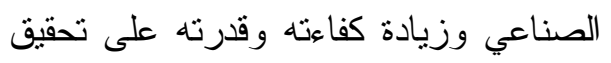

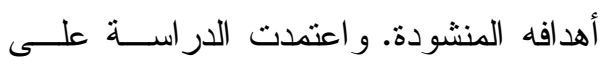

$$
\begin{aligned}
& \text { المنهج الوصفي واستخدمت الدراسة استبانه } \\
& \text { موجهه لعينة من مديري وموجهي ومعلمسي ولئي }
\end{aligned}
$$

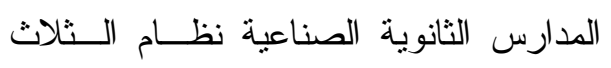

$$
\begin{aligned}
& \text { سنوات وكنلك الأخــصائيين الاجتـــاعيين. } \\
& \text { وتوصلت الدراسة إلى أن أهم مظاهر الهذر الأنئ }
\end{aligned}
$$

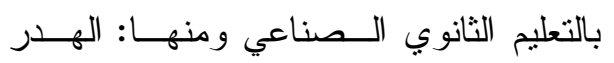

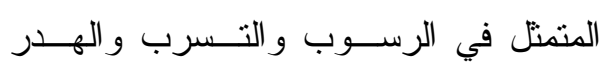

$$
\begin{aligned}
& \text { المرتبط بنوعية التعليم وعدم قــدرة التعلــيم }
\end{aligned}
$$


خسارة كبيرة لأنظمة التعليم في معظــــ دول

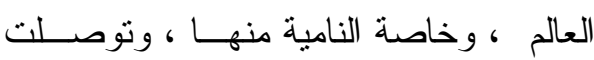
الدر اسة إلى عدة نتائج أهمها:

- لا توجد طريقة مُنّلى يقاس بها الفاقدُ

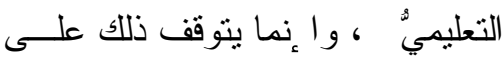
تو افر البيانات و المعلومات. - وجود اختلاف كبير في نسب الفاقــــ

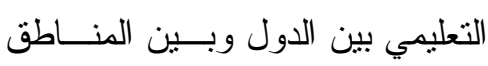
المختلفة في الدولة الواحدة.

- اختلاف نسب التسرب و الرسوب على

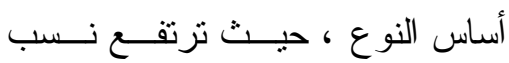

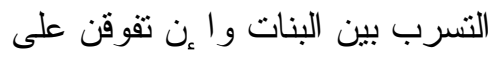
البنين در اسيا في معظم الأحيان. - أقل نسب تسرب في العالم توجد فــي كل من غرب وشرق أوروبا وأمريكا

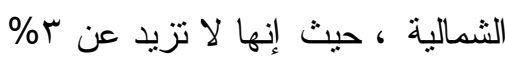

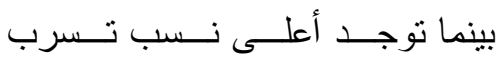

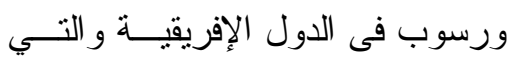
تصل إلى rr\%

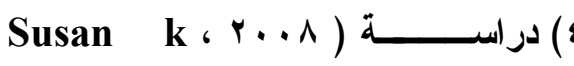
وGardner) بعنوان" نسبة التـسرب بين طلاب الجامعات وأعــضاء هيأـــة التدريس في برامج الاكتوراه بالولايات المتحدة" هدفت الدر اسة إلـى التعــرف علـى

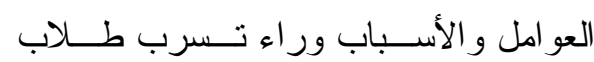

على العملية التعليمية در اسة الأسباب التي تؤدى إلى التسرب.

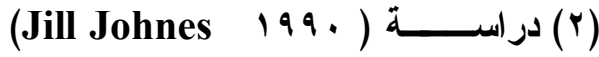
بعنوان : " محددات الفاقد بين طــلاب التعليم العالي"

هدفت الدر اسة إلــى الكـشف عـن محددات الفاقد الموجود بين طـــلاب النعلــيم

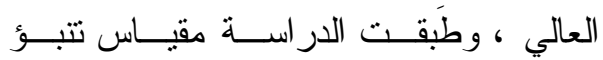

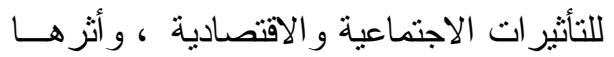
في رسوب الطالب على عينة مــن طــلاب جامعة لانكاستر وعـددهم ( 9 ( ) طالبًّـا وطالبةً ، وقامت الدر استة بمعالجة إحـــائية

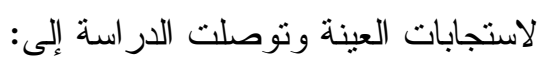
ارتفاع الفاقد بين طلاب التعليم العالي الذين بعانون من نقصٍٍ في بعـضـ الـسمات

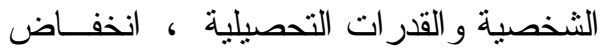

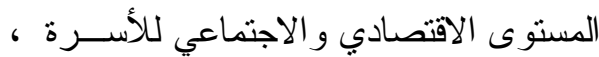

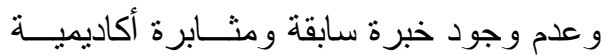
عند الالتحاق بالجامعة لها أثز ها الكبير فــي ارتفاع معدلات الفاقد.

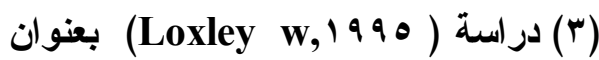

$$
\text { :" الهـر في التعليم". }
$$

هدفت الدراسة إلى الكثف عن الهرر التعليمي الناتج عن الرسوب و التسرب فــي مختلف المر احل التعليمية وفــى دول العــالم

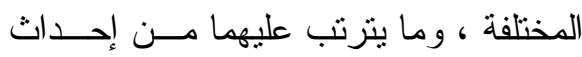


الاتفاق بين الدراســـة الحاليــة و الدراســات السابقة ، وكذلك أوجه الاختلاف بالإضــافة

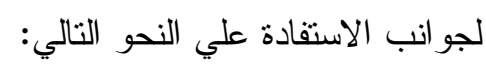

أولا: أوجه الاتفاق بين الدراســـة الحاليــة

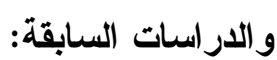

وتتمنل في:

1 - منهج البحث، حيث استخدمت بعـض

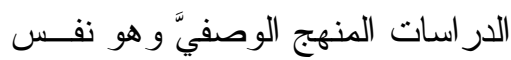

منهج الدر اسة الحالية.

r- اتفقت الدراسة الحالية مع الدراســات

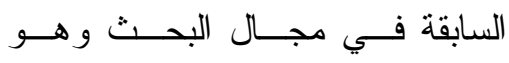

الهدر التعليمي.

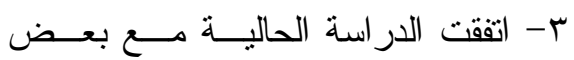

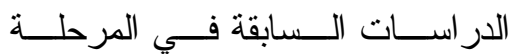

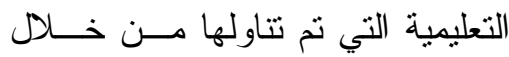

$$
\text { موضوع الدراسة. }
$$

ع- أدوات البحث ، اتفقت الدراسة الحالية

مع بعض الدراسات السابقة في اختيار أداة البحث ، و هي الاستبانة.

ثانيا: أوجه الاختلاف بين الدراسة الحاليــة

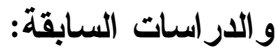

$$
\text { وتتمنل في: }
$$

1- مشكلة البحث ، حيث بهـتم البحــث

الحالي بدر اسة أهم مشكلات أعمــال

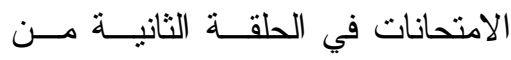

$$
\text { التعليم الأساسي - التي }
$$

الدكتور اه ، و العلاقة بين ارتفــاع معـــلات

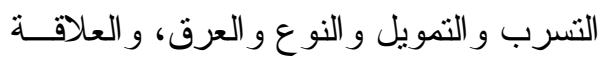

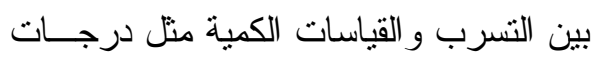
الاختبار وخبــر ات التطبيــع الاجتمـــاعي. وتوصلت الدر اسة إلى أن معدلات التـسرب التسب

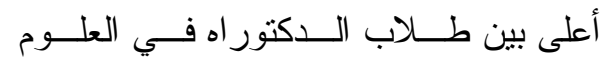
الإنسانية والاجتماعية مقابل العلوم الطبيعيـــة

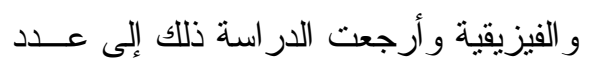
من العو امل منها أسباب أكاديمية منل ( فقدان الطالب القدرة البحثنية ، و الدافعية ، و الحافز ،

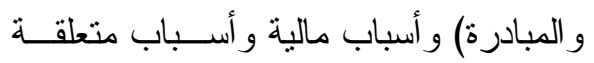

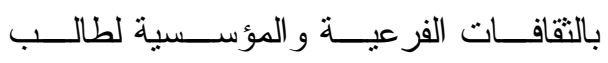
الدكتور اه ، و أكدت الدر اســـة علــى أهميــة

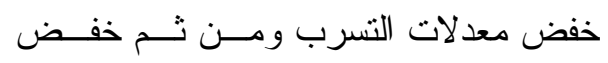
التكلفة. التعليق علي الدراسات السابقة: تتاول الباحث فــي الجـز ء الــسابق مجموعة من الدراسات السابقة ذات الــصلة بموضوع الدراسة الحالية ،حيث تتاولت هذة الدر اسات موضوع الدر اســـة الحاليــة مــن

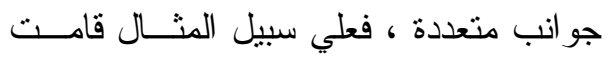

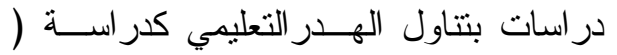

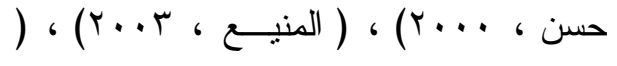

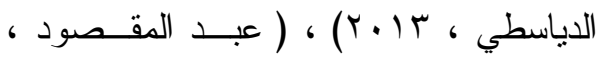

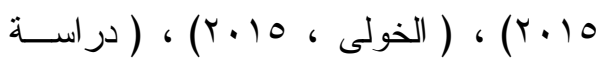
المركز القومي للبحوث التزبوية والتتميــة، التها،

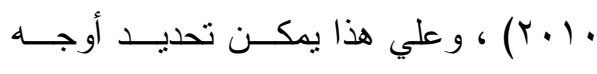




$$
\begin{aligned}
& \text { 0- معاونة الباحــث فـي تحديـــــــــهج } \\
& \text { و أدو ات البحث. } \\
& \text { 1- مساعدة الباحث في تحليـلـ وتفـسير } \\
& \text { نتائج البحث } \\
& \text { إجرائات البحث }
\end{aligned}
$$

أولا: الاطلاع علي الأدبيات البحثية ،

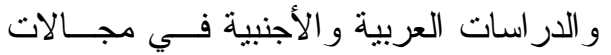
العلوم التربوية ، ومنْ ثَمََّ التأصيل لمـشـكلة البحث ومتغير اتها، وقد نت عرض إجــــر اءات

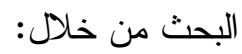
أولا : إطار نظري

ثناتيا : الدراسة الميداتية

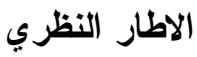

تلعب الامتحانات دور ا هاما في حيـاة

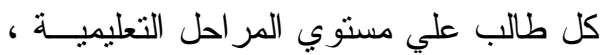
فتؤثز نتائجها عليه بالإيجــاب أو بالــسلب، وينعكس ذلك علي تصرفاته وسلوكياته حيال

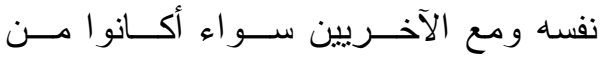

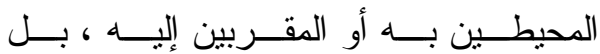

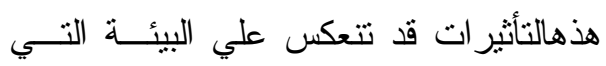

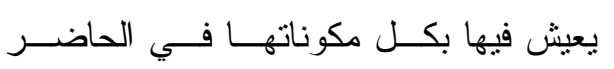

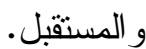

المحور الأول : مشكلات أعمال الامتحانــات في صفوف النقل بالحلقة الثانية من التعليم r- مكان البحث ، و هو محافظة الدقهلية. r- الأهداف التي يـسعي البحــث الــي تحقيقها. ع - أدوات البحث ، فقد اختلــــ البحـــ الحالي مع بعض الدراسات الــسابقة في اختيار أداة البحث. بعة 0- عيّنة البحث، اختلف البحث الحــالي مع بعض الدراسات السابقة في طبيعة عينة البحث. ثالثا: أوجه التمايز لهذه الار اسة: وتتمنل في:

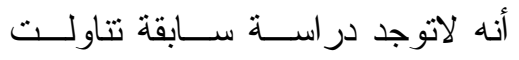
مظاهر الفاقد الكمـــي النـاتج مــن أعمـــال الامتحانات في صفوف النقل بالحلقة الثانيــــة من التعليم الأساسي على حد علم الباحث. رابعا: أوجه استفادة البحــث الحسالي مـن

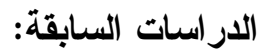
تتمنل اوجه الاستفادة في: 1- صياغة مشكلة البحث الحالي. r- مساعدة الباحث فـي اختيــار مــنهج البحث. - (البعا r- مساعدة الباحث في صياغة تـساؤلات

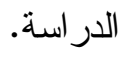
ع - مساعدة الباحث فــي اختيـار عينــة الدر اسة. 
التربية و الهيئــات المـسئولة عــن التعلــيم

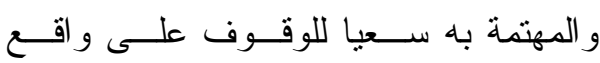
مشكلاتها ، وبحثا عن التحديات التي تو اجهريا

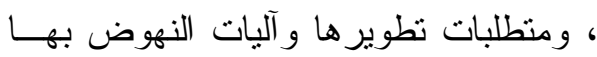
في ظل الحالة الاقتصادية للدولة ، وفى ظل ونل

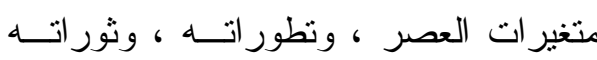

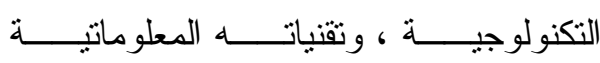

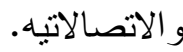

وتـشير الــشو اهد إلـــى أن إعمـــال

الامتحانات في صفوف النقل بالحلقة الثانيـــة

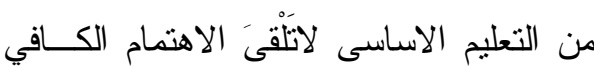

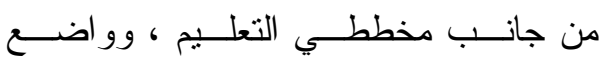
السياسات التعليمية في مصر ؛ للوقوف على كفاءتها ولا يتم التركيـز علـى مسشكلاتها وتقدير حجمها ورصد أبعادها مع أن أعمال الامتحانات تحديدا لابد أن تتال اهنمامًا كبيرًا

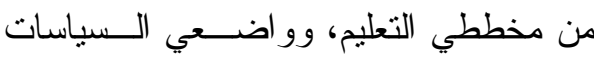
التعليمية للوقوف على الكفاءة الكمية للنظــام

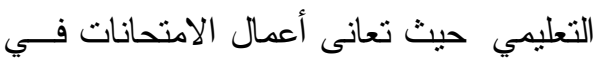
صفوف النقل بالحلقة الثانيــة مــن التعلــيم

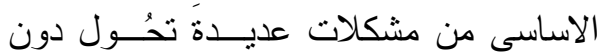

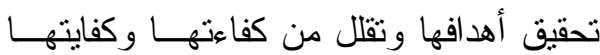

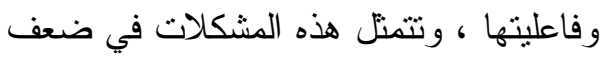
الاستفادة من الإمكانيات، و الطاقات الماديــة ولتهنة

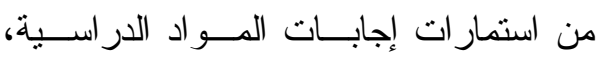
وكثوف الرصـــ، و اســتمار ات الغيــاب ،

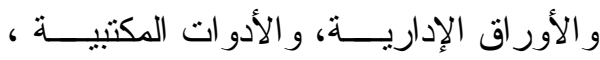

يتم تقييم المتعلمين مــن قبــلـ وزارة

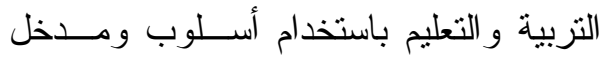
النمو السنوي الذي يركز علي أن المتعلمـين ولين

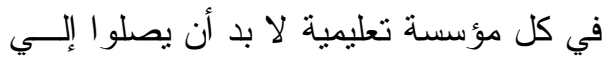
مستوى كاف من التحصيل في مجموعة من

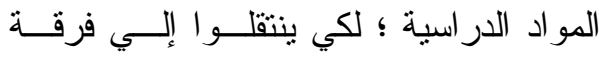

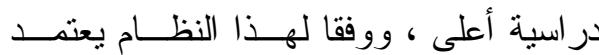
التقييم علي درجات المنعلم في نهايــة العــام

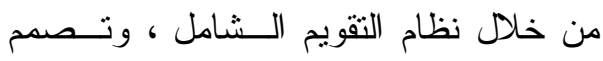
اختبار ات لسنو ات النقل حيث تسمح بـإجر اء لـاء

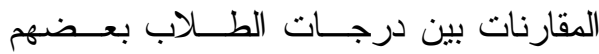
البعض ، وتصمم اختبار ات عامة في نهايــة كل مرحلة تعليمية تسمح بإجر اء المقارنــات بين المؤسسات التعليمية و المحافظات. تُعتبر نُظُُ الامتحان و أعمالها جــزءعًا أساسيًا في العملية التعليمية ، فهي قوة مؤثرة تكثثف عن مدي فاعلية التدريس و المنــاهج و الكتب المدرسية ، وتكثف عن مدي إيجابية

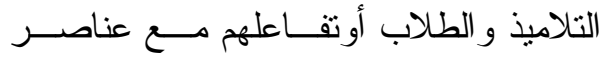
محتوي التعليم ، ولهذا فإن نتيجة الامتحــان أنسان تصلح لأن تكون نقطة انطلاق لإحداث كثير

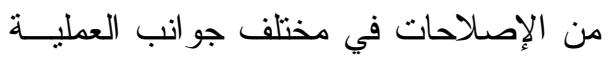

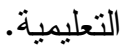

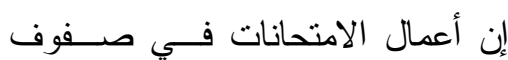
النقل بالحلقة الثانية مـن التعـــيم الاساسـى

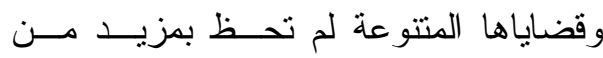
الاهتمام من قبل الباحثنين و المفكرين ورجال 
في الامتحان، وفي هذه الحالة لا يتجه التعليم

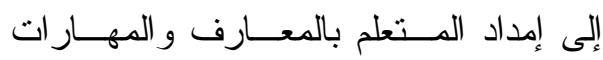

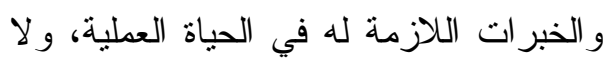
يعمل على تكوين شخصية متكاملة ومتّـسقة في نموها، بل إن التعليم يكون تبعًا لذلك من بن بن

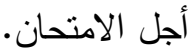

ويرد المدافعون عن الامتحان بقولهم: إن المسؤول عن ذلك ليس الامتحان نفسه بل الامن بون

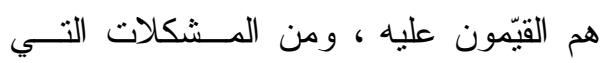
يثير ها الامتحان مشكلة إنماء النزعة الفردية وتتجيع التتافس غير الثريف بين التلاميــذـ،

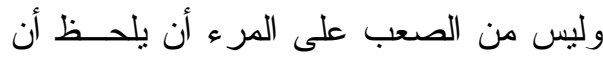

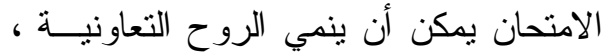
ويشجع التتافس الثريف أيضًا.

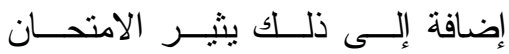
مشكلات أخرى كثيرة فـــي غايـــة الأهميـــة كمشكلات الرسوب والتسرب من المدرســة و القلق و الغش وسو اها ، ولكل منها جو انبها المختلفة التي تتجاوز موضــوع الامتحـــان بصورة عامة والتي يجب در استها في كامل

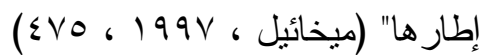
وبالإضافة إلى ذلك فقد اخذ التلاميــذ يفكرون في الوسائل التي تؤدى إلى نجاحهم

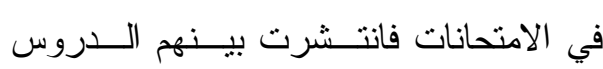
الخصوصية وما لها من أضــر ار ، ولجـــأ بعضهم إلى الغش فـــي أداء الامتحانــات إذا فـا

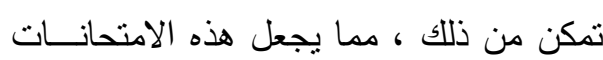

و القوى البشرية ، و الوقت المهرر و المستغرق

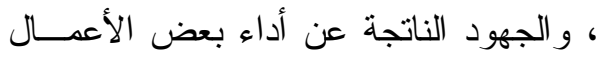

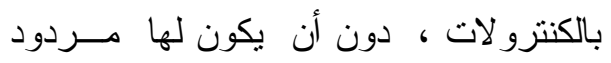

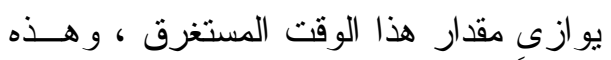

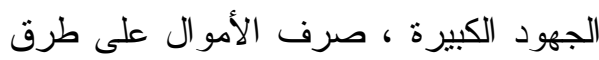
وأساليب نستخدم في أعمال الامتحانات دون أن يكون لها مردود جيد موازٍ لحجم ما ينفق ، عدم وجود معيار للصرف علــى أعهــال الامتحانات في الحلقة الثانيــة مــن التعلــيم الاساسى مما يؤدى إلى فاقد كمي في الإنفاق

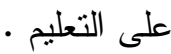
"يثثير الامتحان فـي و اقــع إجرائــهـ وتتظيمه وفيما يؤدي إليه من نتائج، مشكلات كثيرة ما تزال موضع بحث وتأييد ونقد بين المدافعين عن الامتحانات و المعارضين لهــا،

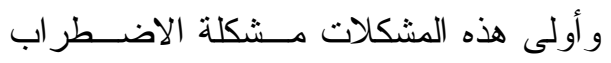
و الفوضى في الجو الددرسي، وتعطيل نظام الدروس، ويرد المــدافعون عـن الامتحـــان

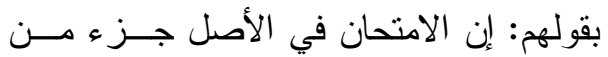

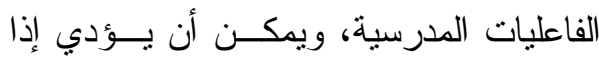

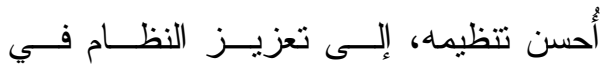

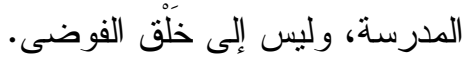
و المشكلة الثانية التي يثيرها الامتحان هي أنه يعطي الأولوية للمعــارف اللفظيــة وحفظها، ويفرض سـيطرنه علـى الحيــاة

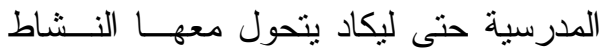
المدرسي برمته إلى سعي من أجل النجـــاح 
الطلاب رصد الــدرجات الحاصــل عليهــــا الطلاب باستمارة الإجابة في كثوف الرصد رصدات

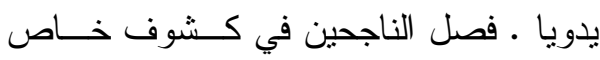

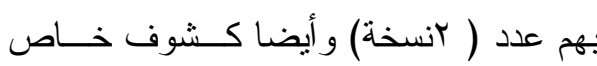

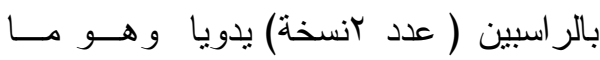
يسمى نتييض النتيجة.

هذا ويلعب التقويم التزبوي الـششامل

دورا مهما في العملية التعليمية ، وهو جزء لا يتجز أ منها، فـــياسات ونظــــام التقــويم

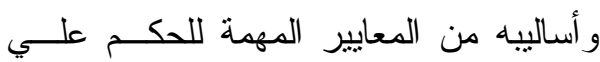

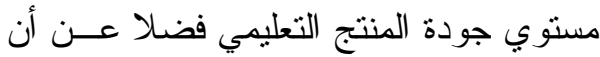

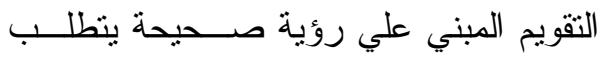

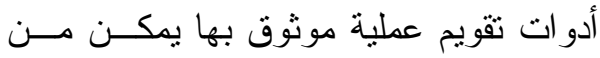
خلالها جمع الثواهد و الأدلة التي تقود إلــي لهي

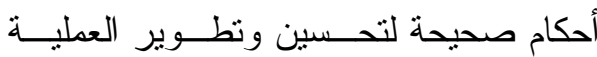
التعليمية ( وزارة التربية و التعليم ، 1... ؟، و علي الرغم من المميــز ات الكثيـــــة

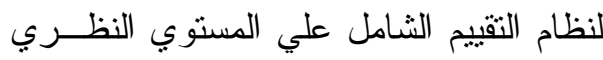
إلا أنه أسفر عن مشكلات في التطبيق نظرا

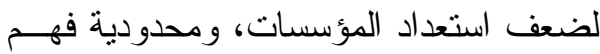
المعلمين و القيادات التعليمية و أولياء الأمسـور

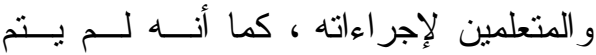
تطويعه و استخدامه في تتبع نمو المتعلمــين

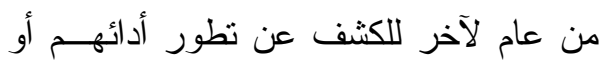

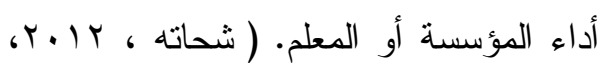

وسيلة قياس غير صادقة فضلا عن النواحي

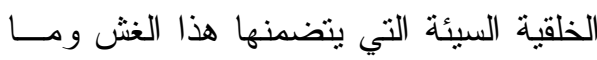

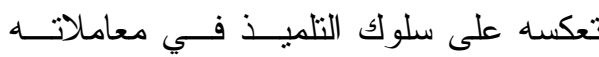
مستقبلا. أصبحت الامتحانات غاية في ذاتهــا. على الرغم من أنها أداة يجب أن نوصلنا إلي الي

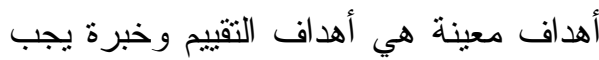
أن يستقيد منها التلميذ و المــدرس و المــنهج

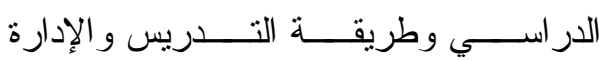

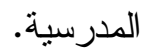
ولقد أوجد الامتحان جدلا كثير ا حوله

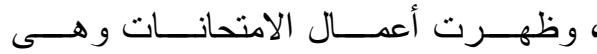
الإجر اءات التي تسبق بدء الامتحان و إثتـــاءه

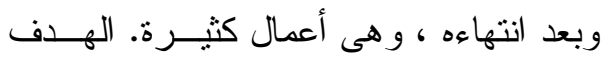

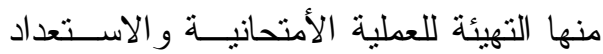

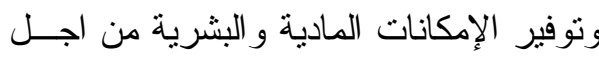

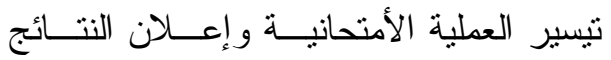

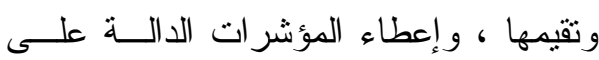
النجاح أو الفشل في تحقيق النواتج التعليمية. ان اعمال الامتحانات الكثبرة وخاصة الاعمال المتعلقة بالكنترولات اوجدت الكثير

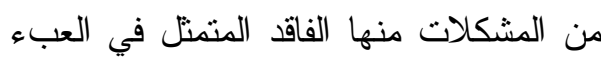

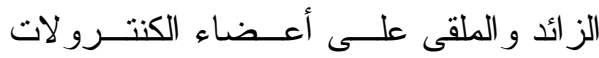

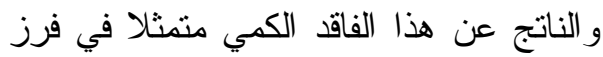

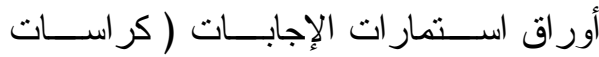

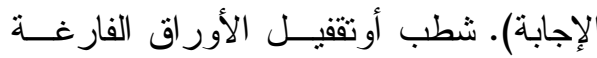

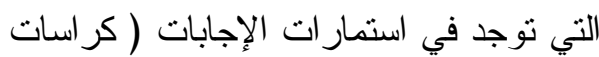
الإجابة) و التي لم يدون بها ايى إجابة من قبل 
وقد وجه سليمان نقدًا للاختبار ات التحصيلية

أدوات التقويم الموثوق بها، و التي من

التقليدية أنها:

خلالها تجمع الثو اهد و الأدلة التي تقود إلـي لـي

- تغطي أجزاء محــددة مــن المقـرر

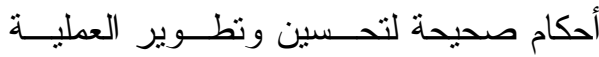

الدراسي السابق دراسته، لذا قد تكون

غير صادقة في قياس الصفة.

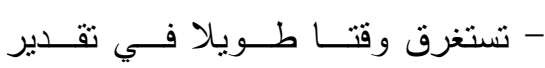

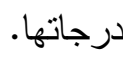

- تثأثز بذاتية المصحح ، حيث نتوقـف

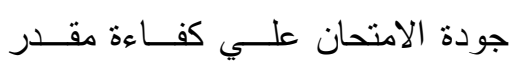

الدرجات.

- قد تلعب الصدفة دورًا كبيرًا في نجاح

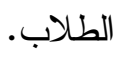

- تسدح للطالب بالتحايل و المر اوغة في

$$
\text { الإجابة. }
$$

الاختبار ات التحصيلية الموضوعية أنها:

$$
\text { - تعجز عن قياس الجانــب الانفعـالي }
$$

- لاتقيس العمليات العقلية العليا.

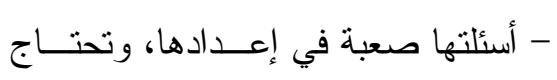

$$
\text { إلي مهارة عالية في إعدادها. }
$$

$$
\text { - مكلفة ماديًّا. }
$$

- تسمح بالتخمين ، وقد تـساعد علــي

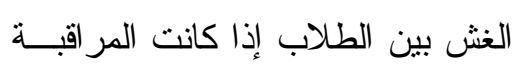

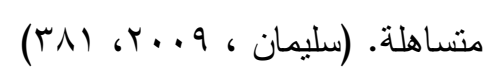

التعليمية هي أعمال الامتحانات، وإجر اءاتها

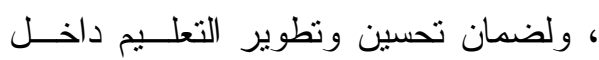

مدارس التعليم الأساسي بحلقتيــــه الابتدائيـــة

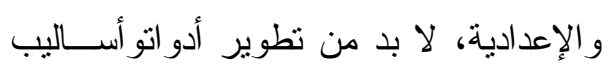

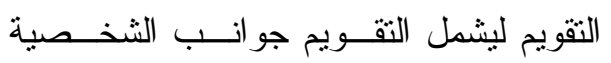

و الوجدانية والحركية ، وعدم الاقتصار علي لئي

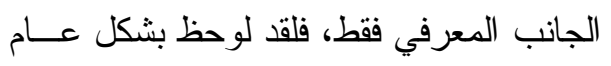

غياب استخدام أدو ات و أساليب تقويم منطورة

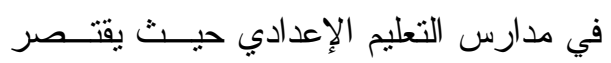

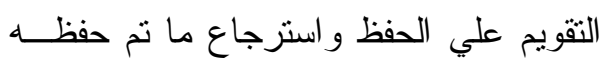

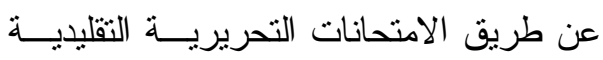

$$
\text { (البنك الدولي ، 0. . ب، ع ع (). }
$$

وتختلف أعمال الامتحانات بــاختلاف

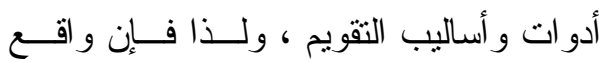

الامتحانات برتبط ارتباطا وثثقًا بو اقع أعمالها

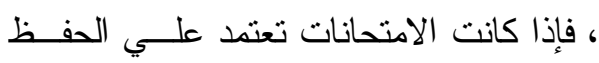

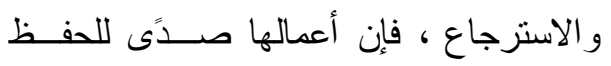

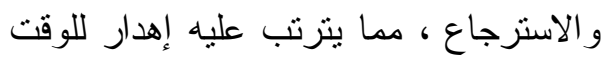

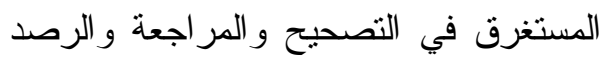

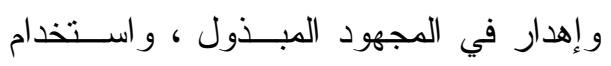

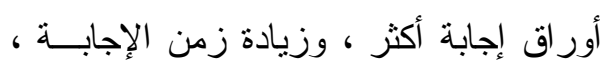

وهو ما يؤدي إلي فاقد كمي مادي بالأعمال

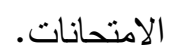




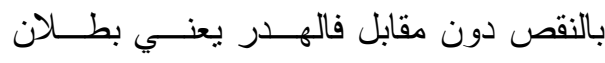

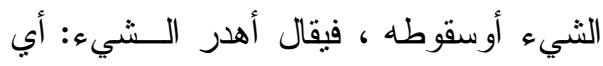

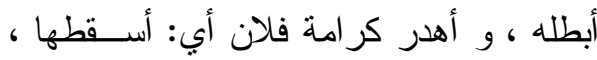

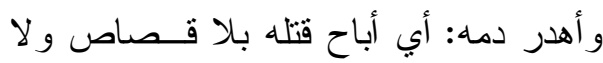

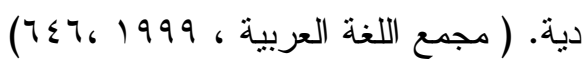
تعريف الفاقد اصطلاحا: يمكن تعريف الفاقد التعليمي بأنه عدم كفاءة النظام في إعداد الموارد البشرية فــي لفي لهئ

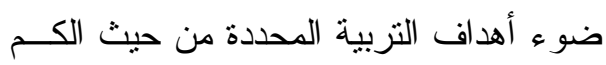
أو التخصص أودرجة الكفـــاءة المتوقعــة. (

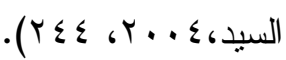

ويعرف الباحث الفاقت الكمـــي فــي اعـــال

$$
\text { الامتحانات اجراعيا : }
$$

ضعف الاســتفادة مــن اســنمار ات

الإجابات للمو اد الدر اسية المختلفة وكــشوف الأف

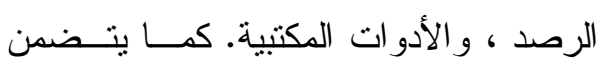

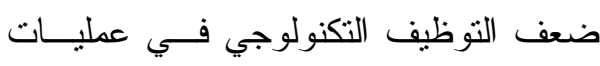
رصد الدرجات وإعلان النتيجة ، وما ينرتب عليه من وقت مستغرق و استتز اف للطاتــات

$$
\text { البشرية. }
$$

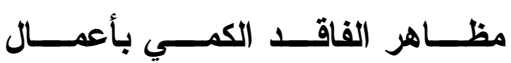

الامتحانات في صفوف النقل بالحقة الثانية من التعليم الأسساسي:

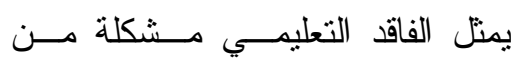

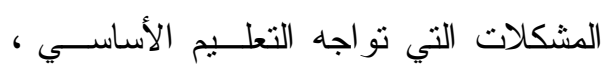

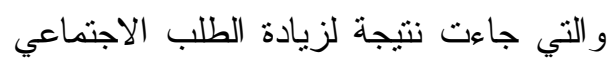

ومن هذا نجد أن أعمال الامتحانــات

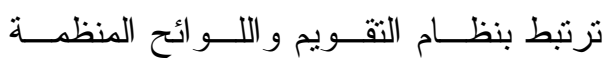
لأعمالها ، وكذلك أسلوب الورقة الامتحانيـــة

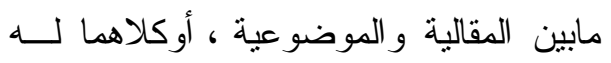

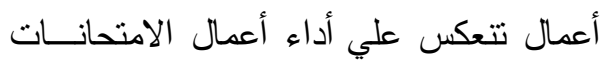

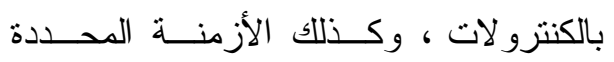
للامتحان ، و عدد الفترات ، و الكثافة الطلابية

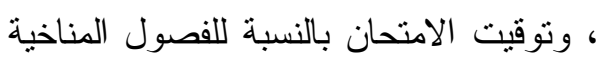

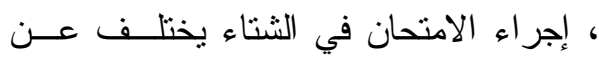
إجر ائه في الصيف ؛ فالصيف أكثر إرهاةً الرّا

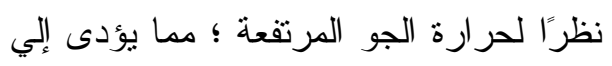

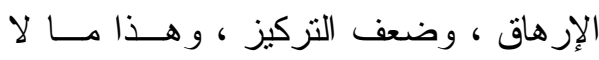
تتطلبه أعمال الامتحانات.

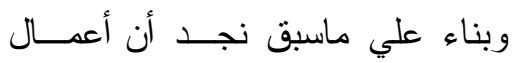

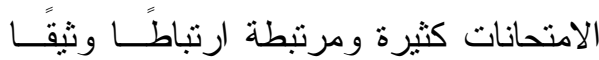

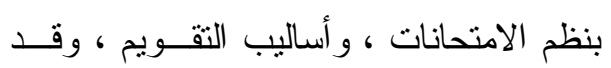
أوجدت مشكلات كثبرة مما أدي إلي حالــة ولـة

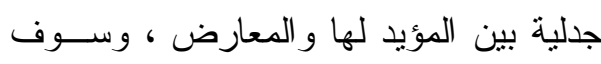

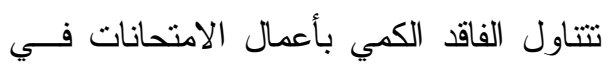
صفوف النقل بالحلقة الثانيــة مــن التعلــيم الاساسي. المحور الثــاني: الفاقــــ الكمـــي بأعمــال الامتحانات في صفوف النقل بالحلقة الثانية من التعليم الاساسي. تعريف الفاقد لغويا:

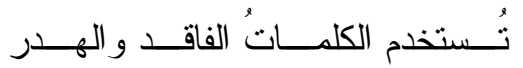
و الضياع و الفقد و الإهدار لتعبر عن الـشيء ولثيء 
- زيادة الجهد الناتج عن ضـــق خانــات كثوف الرصد بما يؤدي إلي الإر هاق. - الهدر الناتج من زيــادة عــدد كــشوف

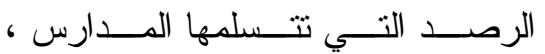
بالإضافة إلي طباعة النتيجة باســتخدام

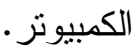

- زيادة عــدد الأوراق المـستخدمة فـي

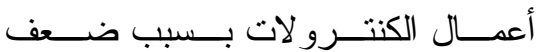
التوظيف التكنولوجي لتلك الأعمال.

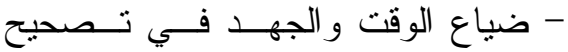
ومر اجعة أوراق إجابة مادة اللغة العربية بسبب تداخل إجابة الطالب في الفـروع المختلفة للمادة.

- غموض معايير أوجه الـصرف علــي الأدوات المستخدمة في الكنتـرول مـنـ ( أقلام - الأحبار - الأوراق - و أدوات مكتبية

وسوف يتتاول الباحث مظاهر الفاقــــ

الكمي المادي بأعمال الامتحانات في صفوف النقل بالحلقة الثانية من التعلــيم الأساســيـي

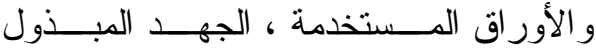
و الوقت المستغرق ، التوظيف التكنولوجي.

أولا- الفاقد الكمي وكثوف الرصد

قبل بداية امتحان الفــصل الدراســي الأول بحو الي شهر تتسلم المدارس من قـسم

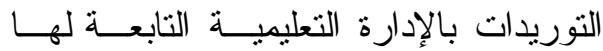

علي التعليم مــن ناحبــة ، وقلـــة المـــوارد الاقتصادية في معظم دول العالم ، وبخاصة الدول النامية ، فالفقد يعني فرصا ومــوارد

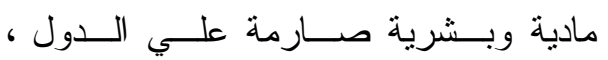
ويحرمها من القدرة علي الاستخدام الأمثــل لمو اردها التعليمية ( المركز القومي للبحوث التزبوية و التتمية ، ع . . Y ، بr). من المشكلات التي تتتج من أعمــال الامتحانات الفاقد الكمي المادي الذي يتوغــل في الكنتزولات، ويري الباحث أن مظــاهر هذا الفاقد تتلخص في الآتي : - زيادة عدد الأوراق في كر اسات الإجابة لمادتي الرياضيات و اللغــــة الانجليزيــــة بصفة خاصة. - زيادة عدد الأقلام المسستخدمة لـشطب الفائض من ورق الإجابة الزائــــ عـن الحد اللازم. - الزيادة في نَسخ كثوف الرصد أكثر من مرة بالكنتزول المطلــوب، و تــسليمها لثشئون الطلبة بالإدارة التعليمية. - نقص عدد أوراق كر اسات إجابة مــادة اللغة العربية مما يــؤدي إلــي نقــص درجات الطالب لعدم وجــود مـسـاحة كافية للإجابة. - ضياع الوقت و الجهد في شطب الأوراق الز ائدة في كر اســـات الإجابـــة لمــادتي الرياضيات و اللغة الإنجليزية. 
يُمتحن فيها الطالب، وذلـــك للــصفين الأول و الثاني الإعدادي في الامتحانات

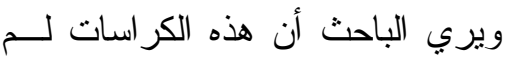

يتم در اسة عدد الأوراق بهم ، بعد تغيير نوع

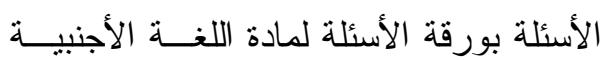

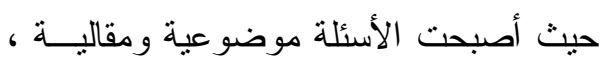
و الأكثرية موضوعية ، وبالنسبة للرياضيات

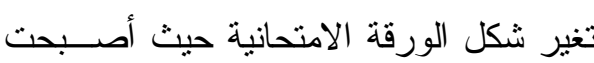
الورقة الامتحانية بها سؤالان موضـــوعيان

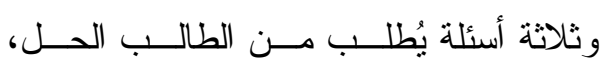

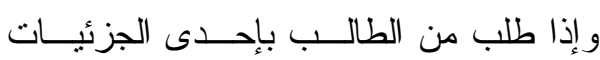

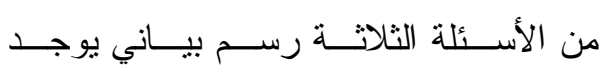

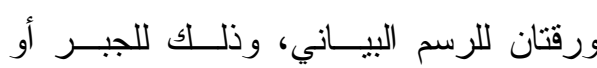

$$
\text { الهندسة. }
$$

من الطرق التي تلعب دور ا كبير ا في

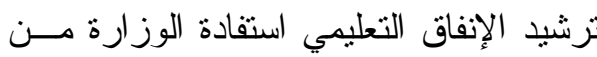

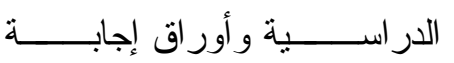

الامتحانات،خاصة أن هذه العناصر تـستهلك ولك

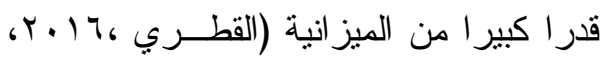

وجود نقص بــأور اق إجابـــة اللغـــة العربية مما يؤدي إلي تداخل إجابات الطالب

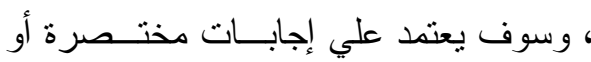
ضعف قدرثه علي توضيح إجابتــهـ بـشكل

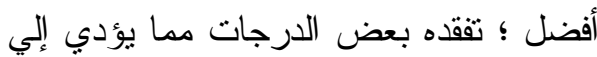

$$
\text { فاقد كمي في درجات الطالب. }
$$

المدرسة عدد من كثوف الرصد بما يتتاسب و عدد الطلاب ، تستخدمها المدرسة في رصد هند

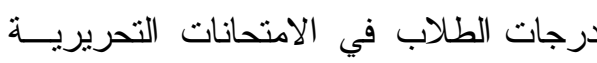
للمو اد الدراسية المختلفة و الامتحانات العملية

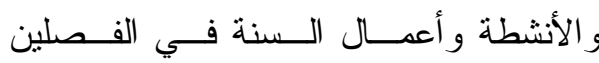

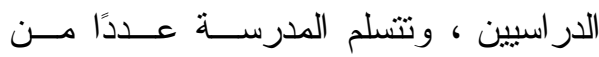
كثوف الرصد يكفي لعمل ثلاث نسخ مــن النتيجة ، وبعد أن سُُحَ للمدارس باســتخدام

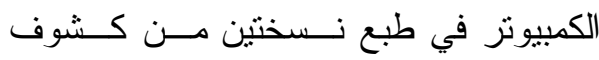

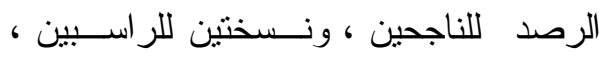

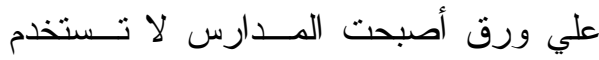
سوي ثلث الكمية من كثوف الرصد المسلمة

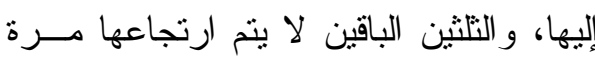

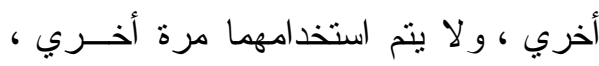
وهو يُعد فاقدًا كميَّا ماديًّا. ويتم حساب عدد كثوف الرصد لصفوف النقل في الحلقة الثانية من التعليم الأساسـي لئي وذللك عن طريق:

$$
\text { عدد كثوف الرصد = }
$$

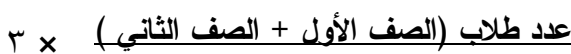

\section{ir}

ثانياـ - الفاقد الكمــي وكراســات الإجابــة (استمارات الإجابة):

يُوز ع علي الطلاب كر اساتُ إجابــة مختلفة في عدد الأوراق حسب المادة التـي 
انعقاد الامتحان ، ومرحلة ما بعد الامتحان ، وهو ما يحتاج إلي وقت مستغرق أكثر مــن الأن

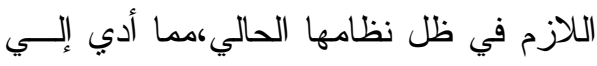

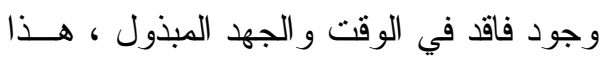

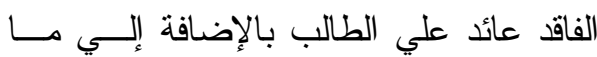

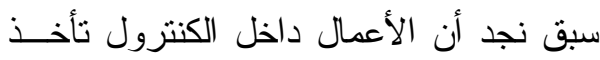

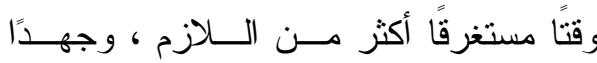

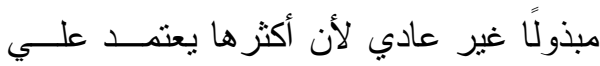
العمل اليدوي، وهذه الأعمال هي:

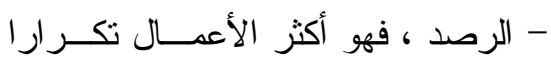
وصعوبة لضيق خانات كشوف الرصد

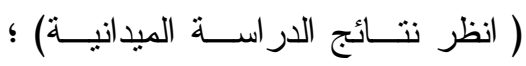
يحتاج إلي دقه بالغة ، ويستغرق وقتَّا أكثز ، وجهدًا مضاعفًا.

- شطب الأوراق الزائدة في كراســات

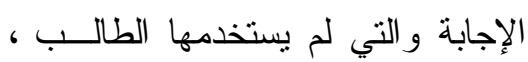

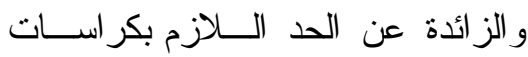
الإجابة لمــادتي الرياضــيات و اللغـــة الانجليزية. - مراجعة أوراق الإجابة لكل مادة بدقة

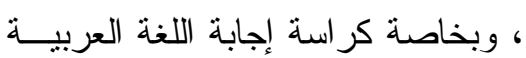

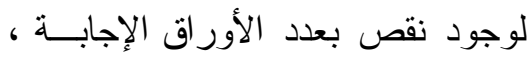

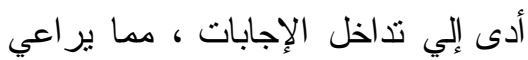

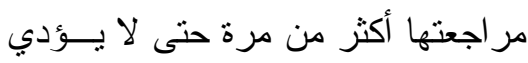
إلي نقص بدرجات الطالب.
وبناء علي ما سبق يعتبر الفاقد الكمي

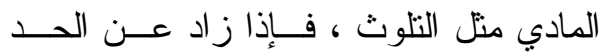

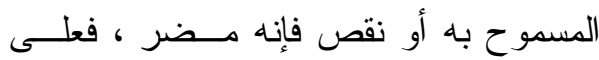

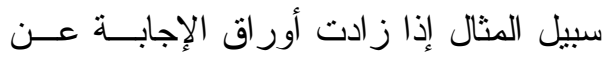

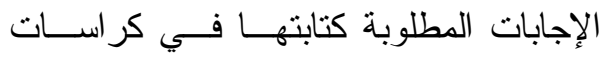
الإجابة من جانب الطالب أصبحت فاقدًا كميًّا في الأدوات المستخدمة في الامتحانات ، و وإذا

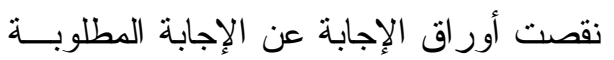

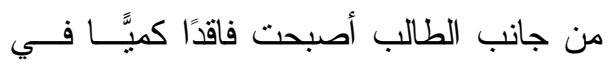

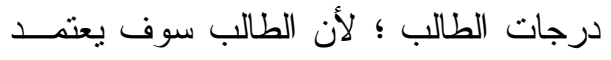

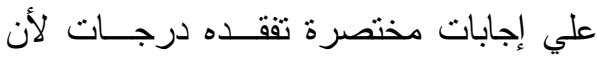
معظم إجاباته غير مكتملة ، أو ضعف قدرنه

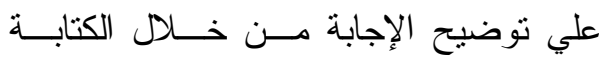

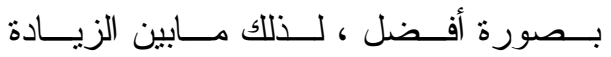
و النقصان لا بد أن يكون هناك نو ازن بحيث

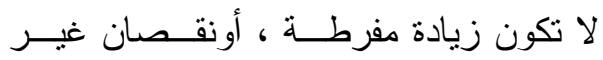

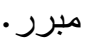

ثالثا- الفاقد الكمي والجهر المبذول والوقت المستغرق بأعمال الامتحانات:

أعمال الامتحانات في صفوف النقــلـ

بالحلقة الثانية من التعليم الأساسـيـي كثيــرة

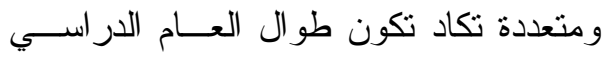

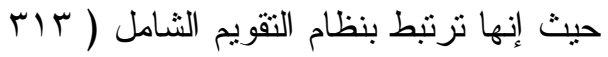

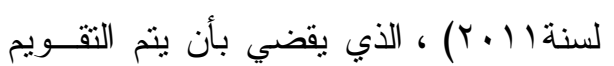
مرنين في نهاية كل فصل در اسي. لئل أعمال الامتحانات تكون علي ثــلات

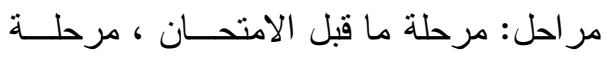


فهناك هدر في المال ، و الوقــت ، و القــوي

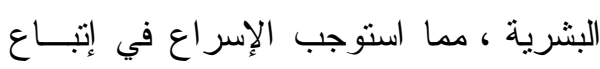

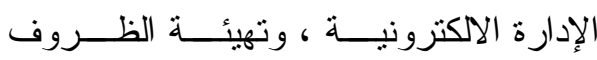

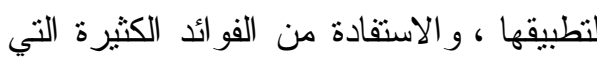
تعود بالنفع علي العملية التعليمية (القطــــري $(r, r \cdot) T_{6}$

فالموارد التعليمية تعاني مــن سـوء

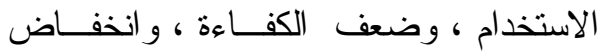
الحافز نحو تحقيق أداء أفضل،وتضخم عـدد الموظفين مما يرفع تكلفة و إعــداد الطــلاب

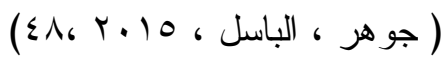

إن الجهاز الإداري التعليمي في جميع مر احله بستخدم أساليبَ مختلفةً في التوثيــن فئن

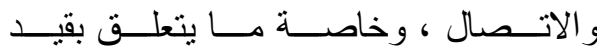

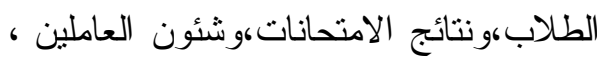

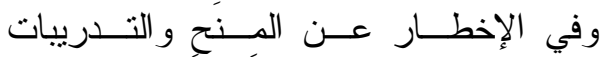
و المؤتمرات، مما يعني إهدار الزمن و الجهد وليح

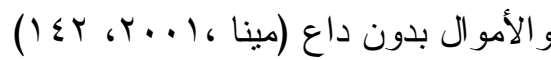
مع التقــدم المعرفــي و التكنولـــوجي التهي

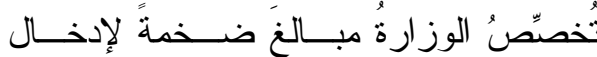

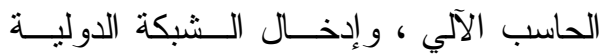

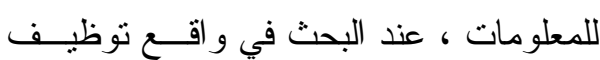
واستخدام أجهزة الحاسب الآلــي والـشبكة

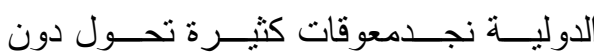
التوظيف الكفء و الفعال لهذه التقنيات ، لذلك يجب السعي نحــو إعــادة تتظــيم الإدارات

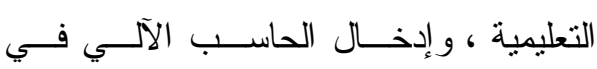

كما أنه لا يوجد تدريب للقائمين علي

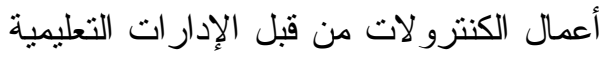

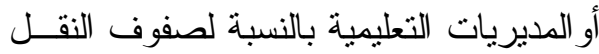

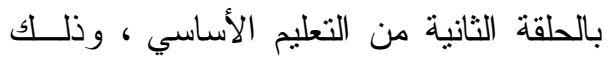

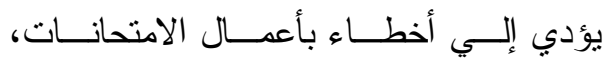
يستوجب إعادتها مرة أخري مما يؤدي إلــي باعي الـي بذل مزيد من الجهذ ، و استنز اف الوقت. رابعا - الفاقد الكمي والتوظيف التكنولوجي

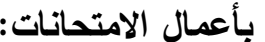

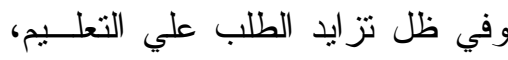

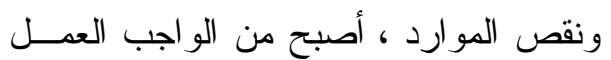

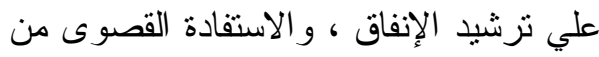

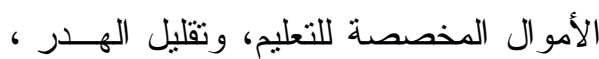
وقد استخدمت مداخل عديدة لترشيد الإنفــاق وتخفيض النفقات ، ومنها: استخدام الحاسب الآلي ، و الثبكات التي تقلل من نكلفة العمل

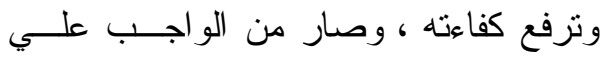
الإدار ات التعليمية أن تستقيد من التكنولوجية من لونية الحديثة في حسل مسـشكلاتها ورفــع كفـــاءة العمليات الإدارية وتحقيق المرونة في العمل بما يرفع من المردود الاقتــــادي للهـــوارد

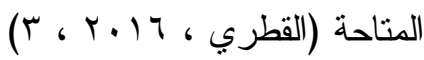
ورغم التطـــور التكنولــوجي ، فــإن الإدار ات التعليمية ماز الت تعتمد علي النظام التقليدي ، و الأسلوب الــورقي ، و اســتمر ار

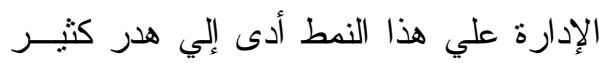

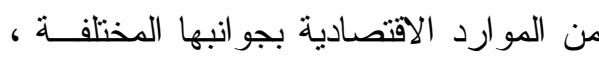


الإدارة التعليمية) وتكلفة ورقة الثيت الواحد

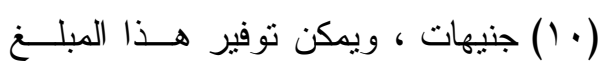

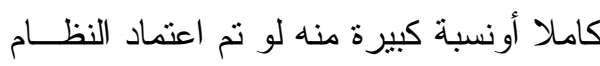

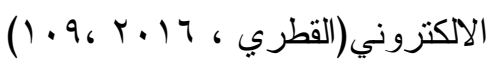

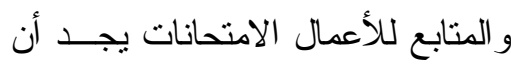

توظيف التكنولوجيا ضعيف جدا حيث أصبح

يتلخص في استخدام الحاســب الآلــي فــي

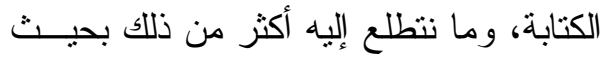

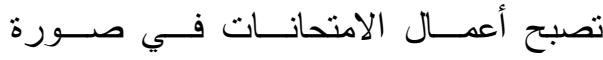
تكنولوجية مما يؤدي في ظل ميزانية التعليم

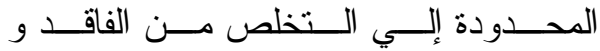
الهدر ،و إعادة نوظيف الأمو ال الناتجــة عــن هذا الهدر في صورة خدمات تعـود علـي

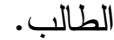

و اللافت للنظر أننا نجد أنـــهـ عنـــما

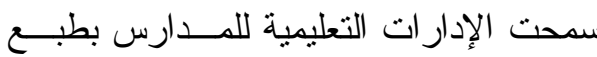
نسختي الناجحين و الر اسبين بالنسبة لكثوف

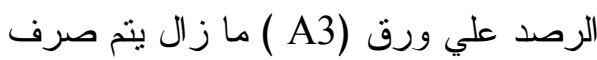
عدد كثوف رصد تكفي ثلاث نسخ. إن التطور التكنولوجيا يفرض علـي النظام التعليمي إعادة النظر في مخرجاتـــهـ ؛

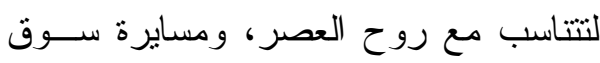
العمل ، و هذا يفرض علي النظــام إدخــال روحال التقنيات الحديثة ، وتفعيلها في تطوير الأداء

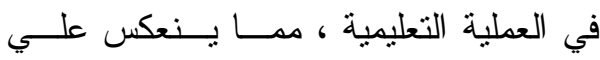
أعمال الامتحانات ، وتقليل أو الحد من هــذا لـال الفاقد أو الهدر . الامنان
منظومة العمل ، وتوظيفه بصورة جيـدة ، ليوفر فــي تكلفــة العـــل، وتحــسين أداء

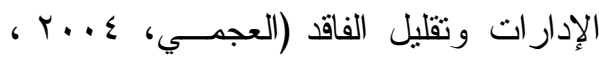
(rOY T Y T و اهتمت الوزارة بإدخــال التقنيــات الحديثة ، وتوصيل المدارس بشبكة الإنترنت ؛ لكي تثبت الدر اسات أنهـــا غيـر مـستغلة الاستغلال الأمثل ، وبعضها غير مسستخدم نهائيا ، بل محفوظة في الحجــرات ؛ لأنهـــا عهدة مما يجعلها عديمة القيمة ، إضافة لعدم توفر إمكانيات النتغيل ، وضعف الـصيانة.

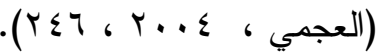

إن الاعتماد علي الأنظمة الاككترونية

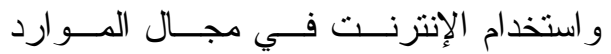

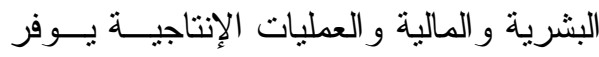

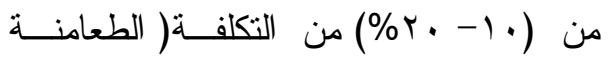

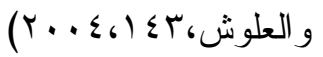
إن إدخال الحاسب الآلي يــوفر •r\% من نكلفة العمل،ويحسن الجهــاز الإداري ، إلـال ويساعد علي التخلص من الهدر و الفاقد فــي مجال التعليم(البحيري ،ع ( ب r ، ب00) وفي شئون الطلاب النظــام الحــالي يحفظ نتائج الطلاب في شيتات ورقية مقاس

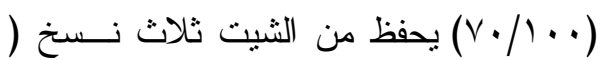
الأصل في كنترول المدرسة ، و الثانية فـي ني

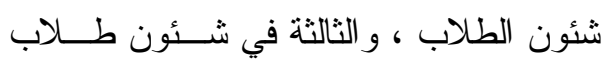




\begin{tabular}{|c|c|}
\hline 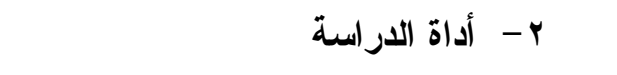 & إجرايات الدراسة الميدانية ونتائجها \\
\hline لتحقيق أهداف الدر اسة الميدانية صمح & تمهيا \\
\hline الباحث استبانة ، وقد مرت عمليــة إعــداد & استكمالاً لما تعرض له البحــث مـن \\
\hline الاسنبانة بالخطوات الآتية: & رؤى نظرية عن بعض مظاهر الفاقد الكمي \\
\hline • •ـ قام الباحث بالاطلاع علــى أدبيـــات & بأعمال الامتحانات لصفوف النقـلـل بالحلةـــة \\
\hline البحث فــى الاطروحـــات العلميــة & الثانية من التعليم الأساسي ومتطلبات الحــد \\
\hline و الابحاث و المر اجع العلمية و التي لها & منهـ وقد سـار الباحـــث فــى هــــه الدر اســـة \\
\hline صلة بموضوع البحث، وذللك بهــدف & الميدانية وفقاً للخطو ات الآتية: \\
\hline صياغة محاور الاستبانة. & أولاً: إجراءات الدراسة الميدانية وتثشمل: \\
\hline 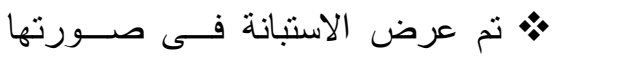 & 1 - أهداف الـــدر اسة. \\
\hline الأولية على السادة المشرفين مكونـــة & r- بـ أداة الـــــدر اسة. \\
\hline من أربعة محاور رئيسة ، وقــــــــــ & ب- عينة الــدر اسة. \\
\hline 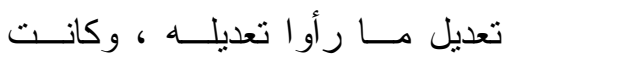 & ثانياً: المعالجة الإحصائية ونتائج الدراســة \\
\hline الاستجابة على المحاور فى صــورة & الميدانية. \\
\hline مقياس ليكرت ثثلاتى (أوافق - إلــى & أولاً: إجراعات الدراسة الميدانية \\
\hline 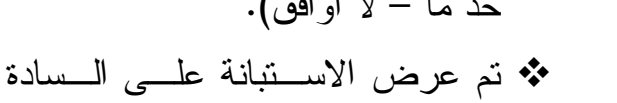 & - \\
\hline & تتمثلّل أهداف الدر اسة الميدانيـــة فــى \\
\hline و المتخصصين، وذللك للتحقــق مــن & \\
\hline مدى ملاعمة الاستبانة للغرض التـى & •ـ التعرف على مظاهر الفاقـــــ الكمــي \\
\hline وضعت من أجله ، ومدى وضــوح & بأعمـــــال الامتحانـــــات لـــــصفوف \\
\hline العبار ات وسلامة الصياغة ، ومــدى & النقل بالحلقـــة الثانيـــة مـــن التعلــيم \\
\hline كفاية العبار ات و الإضــافة إليهـــــأو & نامي \\
\hline الحذف منها. & •• الكثف عن متطلبات الحد من مظاهر \\
\hline ثم قـــام الباحــث بمر اعــاة ملاحظـــات & الفاقد الكمــي بأعمـــال الامتحانـــات \\
\hline ومقترحات السادة المحكمين ، وتمت & لصفوف النقل بالحلقـــة الثانيــــة مــنـن \\
\hline مناقشتها مع السادة المشرفين ، وكان & 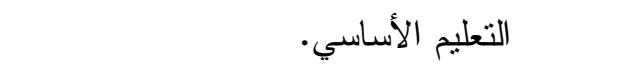 \\
\hline
\end{tabular}




$$
\begin{aligned}
& \text { التدريس وعددهم (7 (1) محكم للتأكد } \\
& \text { من أهم هذه التعديلات حذف عبار ات } \\
& \text { من أن الاستبانة تقيس ما اســتخدمت }
\end{aligned}
$$

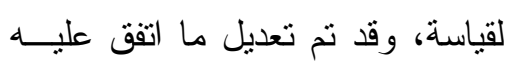

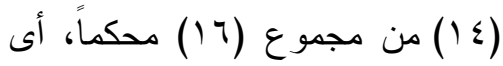

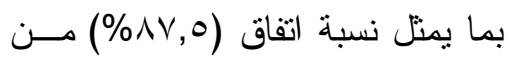

$$
\begin{aligned}
& \text { المحكمين. } \\
& \text { • تم حساب الصدق الأتى للاستبانة }
\end{aligned}
$$

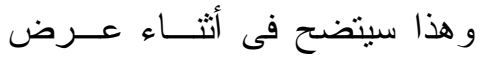

$$
\begin{aligned}
& \text { النبات للاسنبانة. } \\
& \text { • مؤشر صدق الاتــساق الـــاخلى: } \\
& \text { وذلك من خلال: } \\
& \text { • ارنباط درجة كل مفــردة بالدرجــة } \\
& \text { الكلية للمحور : نم حساب معساملات } \\
& \text { ارنباط درجة كل مفــردة بالدرجـة }
\end{aligned}
$$

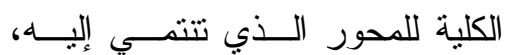

$$
\begin{aligned}
& \text { وجاءت النتائج كما هي مبينة بجدول } \\
& \text { (؟؟؟) وذللك على النحو الآتي: }
\end{aligned}
$$

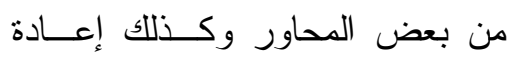

$$
\begin{aligned}
& \text { صياغة بعض العبار ات. }
\end{aligned}
$$

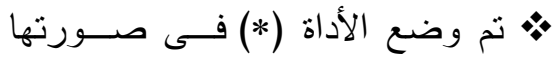

$$
\begin{aligned}
& \text { النهائية مكونة من محاورين رئيسيين } \\
& \text { وهما: } \\
& \text { المحور الأول: مظاهر الفاقد الكمــي } \\
& \text { بأعمال الامتحانات لصفوف النقــل بالحلقـــة } \\
& \text { الثانية من التعليم الأساسي. } \\
& \text { المحور الثاني: متطلبات الحـــــــن }
\end{aligned}
$$

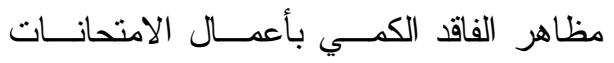

$$
\begin{aligned}
& \text { لصفوف النقل بالحلقة الثانيــة مــن التعلــيم } \\
& \text { الأساسي. } \\
& \text { وللتأكد من مدى صــلاحية هـــه } \\
& \text { الأداة للنطبيق قام الباحث بالآتى: } \\
& \text { أ- - صدق الاسـتبانة: ويعنــى أن ثقـيس } \\
& \text { الاستبانة ما وضعت لقياسه(')، وقد نم } \\
& \text { حساب صدق الاستبانة عن طريق: }
\end{aligned}
$$

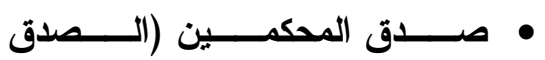

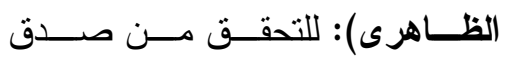

$$
\begin{aligned}
& \text { الاسنبانة تم عرضها على عدد مـن }
\end{aligned}
$$

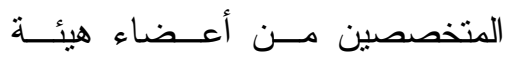


جدول (1) قيم معاملات ارتباط درجة كل مفردة بالارجة الكلية للمحور الذى تنتمى إليه

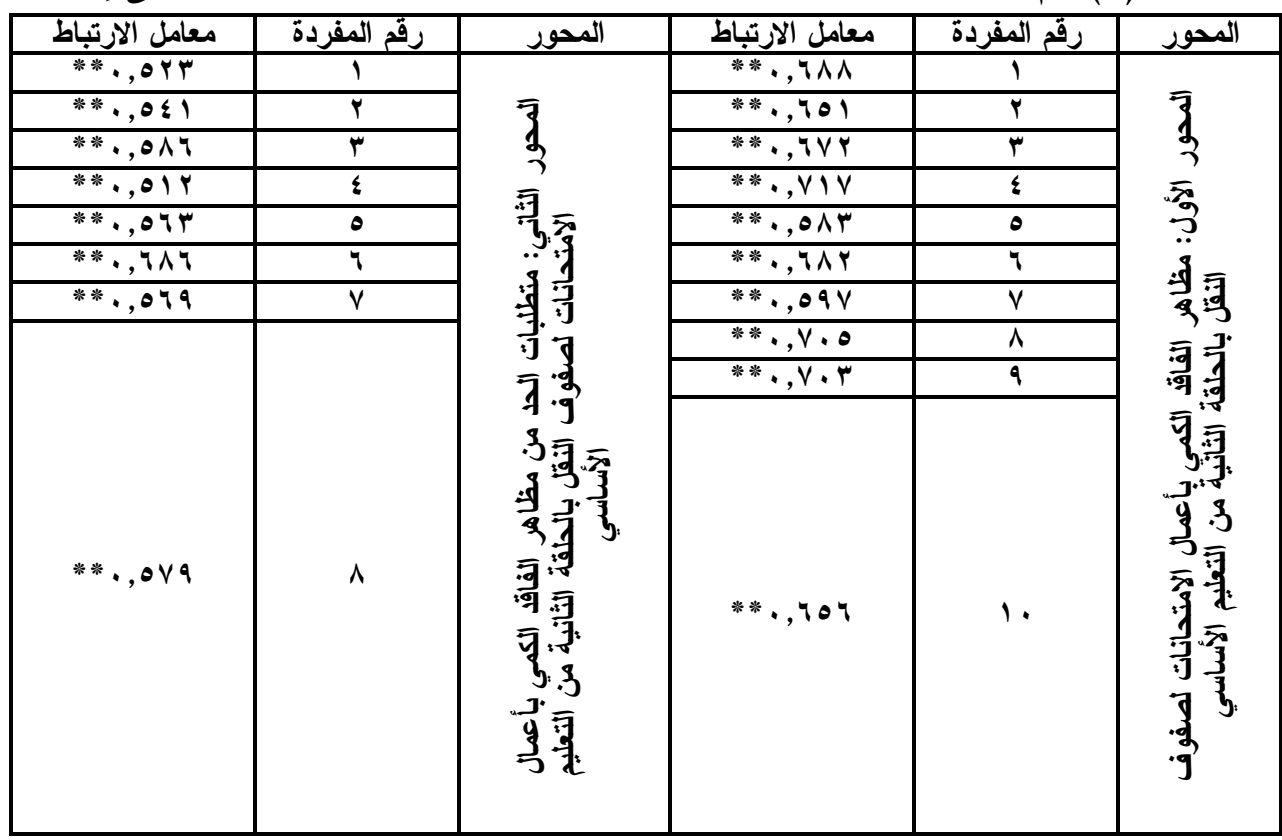

*** تعنى أن الارتباط دال عند مستوى (1 +, •).

درجة كل مفردة و الدرجة الكليــة لهــــا

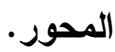

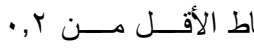

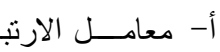

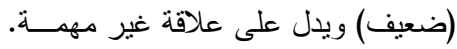

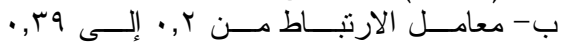
(ضعيف) ويدل على وجود علاقة ضعنيفة.

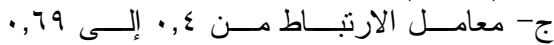
(متوسط) ويدل على علاقة جيدة ومهمة. الارن.

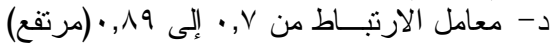

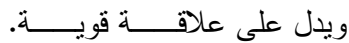

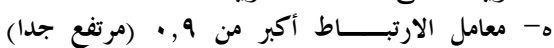

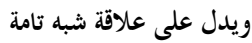

يتضح من جدول (1) أن جميع قـيم

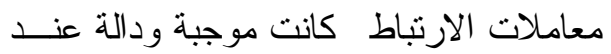

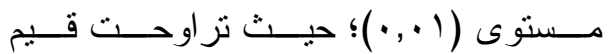
معاملات ارتباط درجة كل مفردة بالدرجــة الكلية للمحاور كالآتى: • بالنسبة للمحــور الأول تراوحست قـئم معـــاملات الارتبـــاط لمفرداتـــهـه بــين

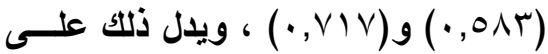
وجود علاقة جيدة ومهمة وقوية (*) بين

" قد اقتر ح جيلفورد تقسير المعاملات الارنباط حسب المبات

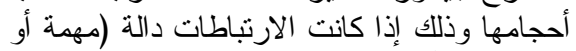

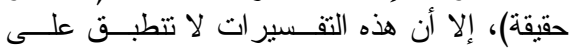

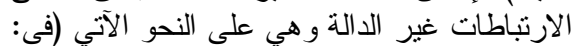

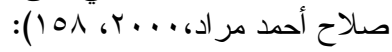


• ارتباط درجة كل محسـور بالدرجـة

الكلية للاستبانة: نم حساب معاملات

ارتباط درجة كل بعد بالدرجة الكليــة

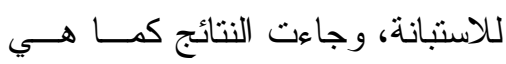

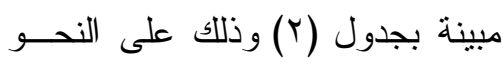

الآتى
ث بالنسبة للمحور الثاني تراوحت قيم

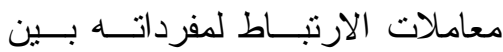

(ع)

على وجود علاقة جيدة ومهمة بـين

درجة كل مفردة و الدرجة الكلية لهذا

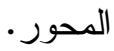

جدول (Y) قيم معاملات ارتباط درجة كل محور بالدرجة الكلية للاستبانة

\begin{tabular}{|c|c|}
\hline معامل ارتباط المحور بالارجة الكلية للاستبانة & 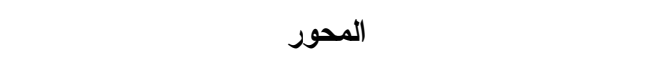 \\
\hline$* *, \wedge \wedge$. & المحور الأول: مظاهر الفاقد الكمي بأعمال الامتحاتـــات \\
\hline$* *, 4 \wedge 4$ & 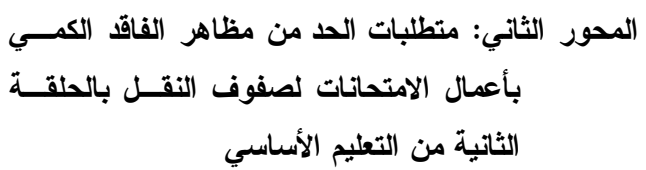 \\
\hline
\end{tabular}

المفحوصين فى ظروف واحدة(1)،

وقد تم حساب ثبات الاستبانة عن

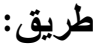

Alpha الثبات بطريقة ألفا كرونباخ

- Chornbach

بحساب ثبات الاستبانة بطريقة ألفــا

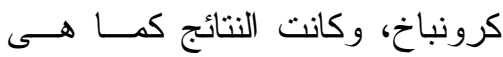

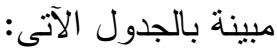

- محمد منير مرسى: البحث التزبوى وكيف نفهمه

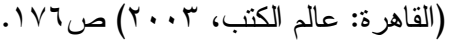

يتضح من جدول (Y) أن جميع قيم

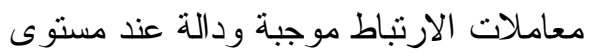

(1)

ارنباط درجة محاور الاستبانة بالدرجة الكلية

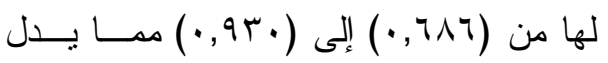

على وجود علاقة جيدة ومهمة وقوية وشـبـا

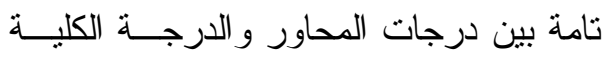

لماستبانة.

ب- ثبات الاستبانة: ويعنى أن الاستبانة

تعطى نتائج واحدة إذا مـــا أعيـــ

تطبيقها على العيـــة ذاتهـــا مــن 
جدول (r) قيم معاملات ثبات "ألفا" لمحاور الاستبانة والدرجة الكلية للاستبانة

\begin{tabular}{|c|c|c|}
\hline (معامل الثبات) & 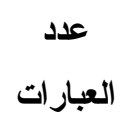 & المحور \\
\hline •, 10 & 1. & المحور الأول: مظاهر الفاقد الكمي بأعمال الامتحانات لصفوف النقل \\
\hline זrT, & $\wedge$ & 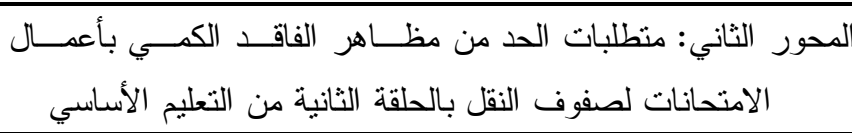 \\
\hline ., $9 \leq \leqslant$ & 11 & الاسنتبانة كاملة \\
\hline
\end{tabular}

و هذا يثير إلى ارتفاع الصدق الــذاتى

للاستبانة.

ب- عينة الاراسة: تكونت عينة الدر اسة من

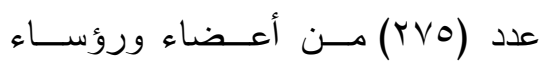

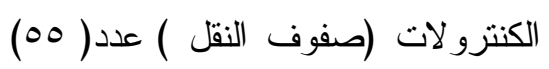

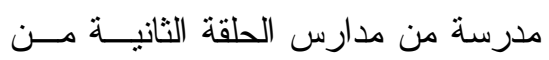
التعليم الأساسي وبيانها الاتي مني مدرسي

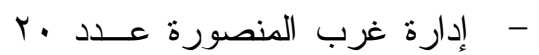

مدرسة من باج مدرسـة بنـسبة

$$
\text { . \%rr }
$$

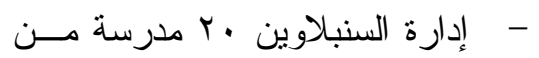

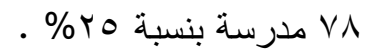

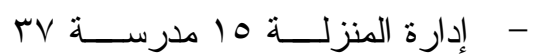

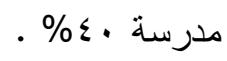

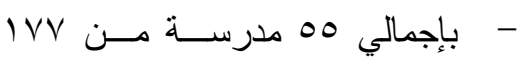

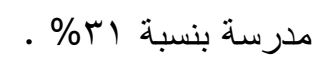

ثانياً: المعالجة الإحصائية وتحليل نتـائج

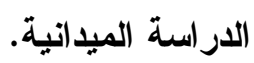

يتضح من نتــائج جـدول رقـم (r)

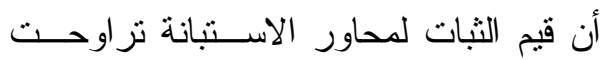

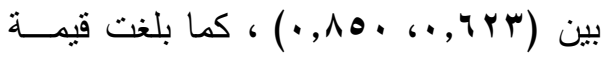

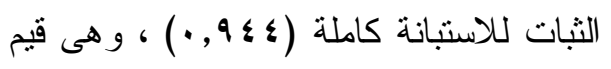

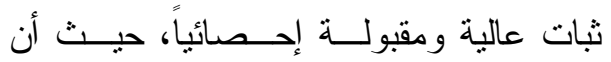

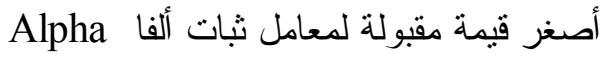

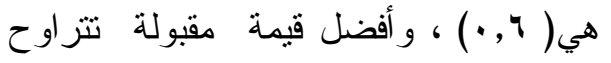

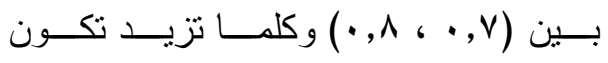
أفضل (r) ( ) ومن ثم فقد تم حساب معامل الــصدق

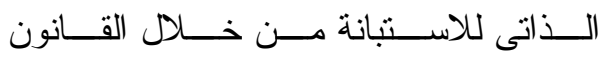
الآتى (r) - (ب)

$=\sqrt{\text { معامل الثبات }} \sqrt{0.944}=0.972=$

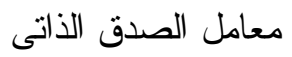

† _ محمود مهاي البياتي: تحليل البيتات الإحصائية باستذام البرنامج الإحصائي SPSS (عمان: دار الحامد للنشر والتوزيع، ه.... ب).

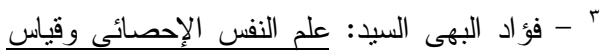

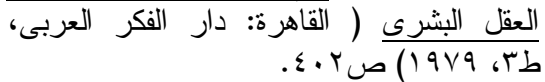




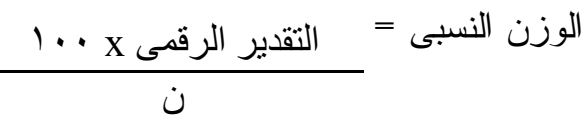

$$
\begin{aligned}
& \text { حيث ن : عدد العينة } \\
& \text { - - ترتيب العبار ات حسب الوزن النسسبى } \\
& \text { أو الأهمية النسبية لكل منها؛ حيث إن: }
\end{aligned}
$$

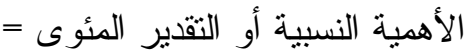

$$
\begin{aligned}
& \text { عدد البدائل النببى }
\end{aligned}
$$

- تم حساب قيمة كا` لحسن المطابقة لكل مفردة، وذلك للكثف عن الفروق فـى اختيار ات أفر اد العينة لبدائل الاســتجابة الثلاثة (أو افق - إلى حد ما - لا أو افق)

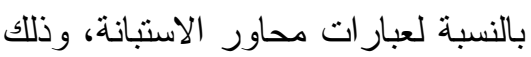
بتطبيق المعادلة الآتية

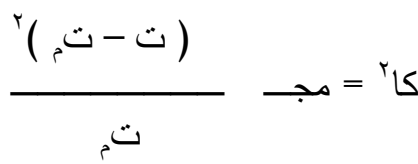

حيث إن ت = النكرار الملاحظ أو التجريبى.

$$
\text { ت م = التكرار المتوقع }
$$

r - تحليل نتائج الارسة اسلميدانية:

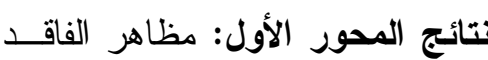

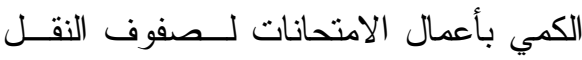

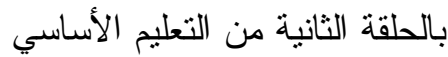
لمعرفة رؤية عينــة الدر اســـة مــن أعضاء ورؤساء الكنتزو لات بالحلقة الثانيــة من التعليم الأساسي و البالغ عـددهم (YVO) مبحوث حول مظاهر الفاقد الكمي بأعمــال

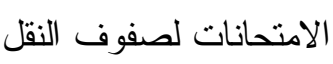

1 - المعالجـــة الإحــصائية: بعــــ تجميــع

الاســـنبانات وفحــــــها و اســــتبعاد

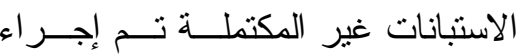

• تفريغ البيانات الور ادة فى استجابات

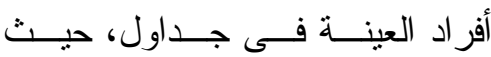

أعطيت (r) درجات للبديل أوافـق، لـان،

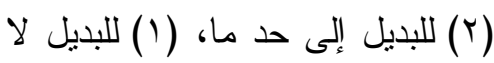
أو افق وذللك فى محاور الاستبانة. • إذخال البيانات على الحاسب الآلـى لـى

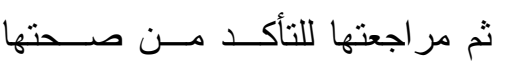
ودقتها.

• اعتمد الباحث فى تحليلـــه للبيانـات إحصائياً على استخدام برنامج الحزم SPSS الإحصائية للعلوم الاجتماعية Statistical Package for the )

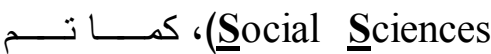
استخدام الأساليب الإحصائة الآتية: -حساب التكر ار ات ونــسبتها لكـلـل مفردة. - مفا -حساب التقدير الرقمى لكل مفــردة من خلال المعادلة الآتية: التقدير الرقمى = (T × نكر ار أو افـق

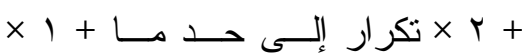
تكر ار لا أو افق).

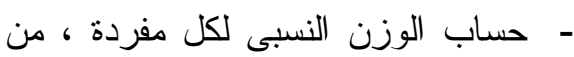

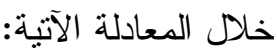




$$
\begin{aligned}
& \text { بالحلقة الثانية من التعليم الأساسـي، الجدول الآتي: }
\end{aligned}
$$

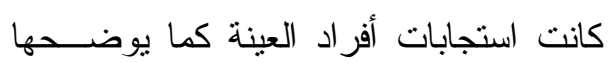

جدول (؛) استجابات عينة الدراسة حول مظاهر الفاقد الكمي بأعمال الامتحانات لصفوف النقل بالحلقة

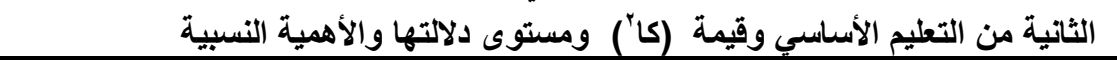

\begin{tabular}{|c|c|c|c|c|c|c|c|c|c|c|}
\hline \multirow{3}{*}{ 羿: } & \multirow{3}{*}{ 承: } & \multirow{3}{*}{ :3 } & \multirow{3}{*}{ كا' } & \multicolumn{6}{|c|}{ البدائل } & \multirow{3}{*}{ العبار ات } \\
\hline & & & & \multicolumn{2}{|c|}{ لا أوافت } & \multicolumn{2}{|c|}{ إلى حد ما } & \multicolumn{2}{|c|}{ أو افق } & \\
\hline & & & & $\%$ & ك5 & $\%$ & 5 & $\%$ & S & \\
\hline $1 \cdot$ & $\wedge 0, \Gamma$ & $\cdot, \cdot 1$ & $1 \leqslant 9$, & 11,7 & r & $r \cdot, v \mid$ & $O V$ & $7 V, 7$ & $1 \wedge 7$ & 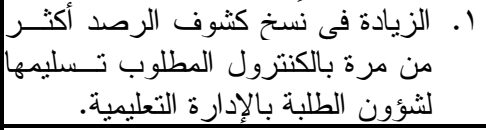 \\
\hline 0 & 19 & $\cdot, \cdot 1$ & ror, & 11,7 & rr & 9,1 & rV & $V \wedge, 0$ & $r, 7$ & 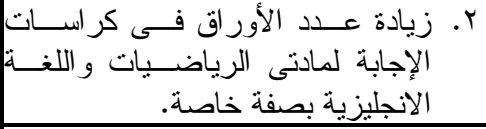 \\
\hline 9 & $\wedge 0, V$ & $\cdot, \cdot 1$ & $I \vee \varepsilon, \wedge$ & $|\Gamma, \wedge|$ & TA & $10, \pi$ & $\varepsilon r$ & $V \cdot, q$ & 190 & 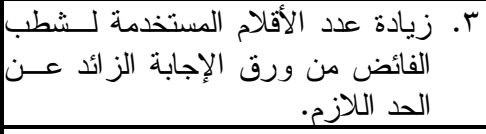 \\
\hline 7 & $\wedge \wedge, 0$ & $\cdot, \cdot 1$ & $r \leqslant q, 0$ & $|r, v|$ & ro & 9,1 & ro & $V \wedge, r$ & Y10 & 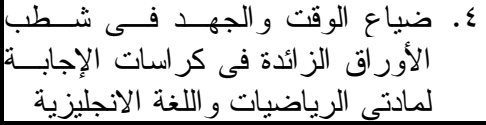 \\
\hline$\wedge$ & $\wedge \bullet, \wedge$ & $\cdot, \cdot 1$ & $1 \leq 9,7$ & $9, \wedge$ & rV & $r r, q$ & Tr & $7 V, r$ & $1 \wedge 0$ & 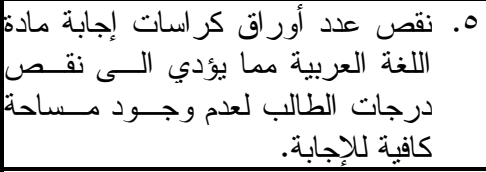 \\
\hline V & $\Lambda V, r$ & $\cdot, \cdot 1$ & 177,7 & $v, r$ & $r$. & $r \leq, \cdot$ & 77 & $\neg \wedge, V$ & $11 \wedge 9$ & 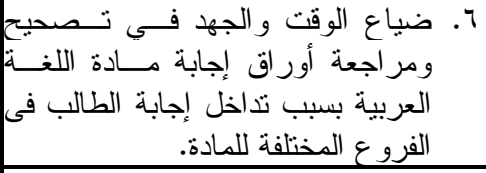 \\
\hline 1 & $9 r, 0$ & $\cdot, \cdot 1$ & r,V & $\varepsilon, V$ & r & $1 \cdot, r$ & r人 & $\wedge 0,1$ & |rrs & 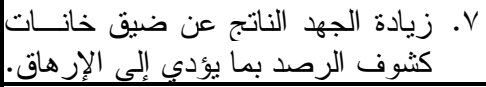 \\
\hline$\varepsilon$ & $\wedge q, \vee$ & $\cdot, \cdot 1$ & YTr,O & $v, r$ & r. & $17, \varepsilon$ & $\varepsilon 0$ & $\vee \vee, \Sigma$ & $41 \cdot$ & 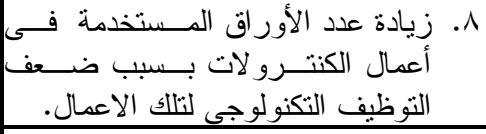 \\
\hline r & $91, \varepsilon$ & $\cdot, \cdot 1$ & r & 0,1 & $1 \varepsilon$ & 10,7 & $\varepsilon r$ & $\vee q, r$ & 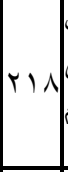 & 9. \\
\hline r & $9 \cdot, 1$ & $\cdot, \cdot 1$ & $r \leq \cdot, \varepsilon$ & 7,9 & 19 & $17, \cdot$ & $\varepsilon \varepsilon$ & $V V, 1$ & YIY & 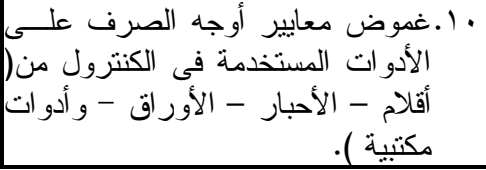 \\
\hline
\end{tabular}


يتضح من نتائج جدول (؛) ما يأتى:

جاءت العبـارة (9) وهـى (الهـــل

الناتج من زيادة عدد كثوف الرصد التــي

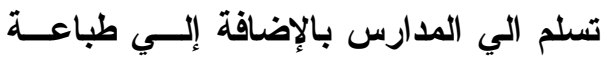

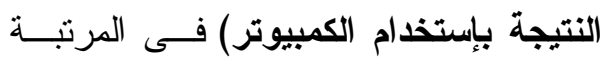

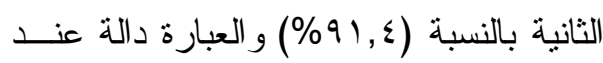

مستوي( ا., +.) ويري الباحث أن هذه النتيجة

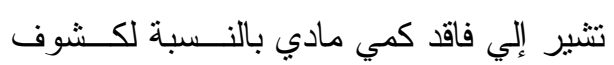
الرصد حيث إن الدرسة تستخدم ثلث العدد بالث السسلم اليها من كثوف الرصد وطباعة باقي النسخ من كثوف الرصد بإستخدام الكمبيوتر بعد أن سمت الإدار ات التعليمية بذللك.

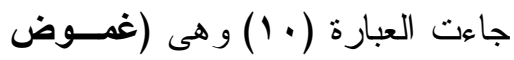
معسيير أوجسهـ الــصرف علــي الأدوات

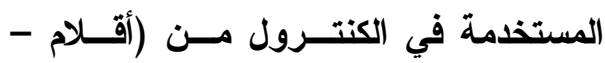

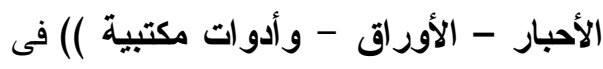
المرنبة الثالثة بالنسبة (1, .9\%) و العبــارة

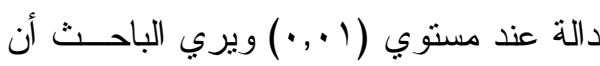
هذه النتيجة تثير إلي أنسه خــالد العـامين

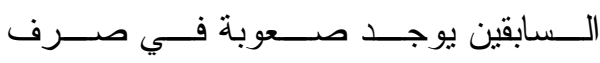
المخصــــات الماليــة لخامـــات أعـــــال الامنحانات من المصروفات الدراسية التـي التي

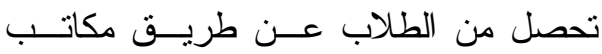

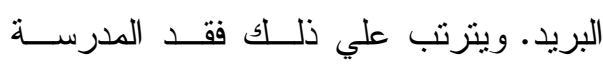
لمخصصانها. جاءت العبارة (0) وهى ( نقص عدد أوراق كراسات إجابة مادة اللغة العربية مما (ناكي
جاءت استجابات عينة الدراسة مـن أعضاء ورؤساء الكنترو لات بالحلقة الثانيـــة من التعليم الأساسي حول مظاهر الفاقد الكمي

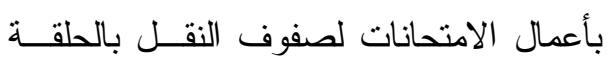
الثانية من التعليم الأساسي بأن هناك فروقـاً

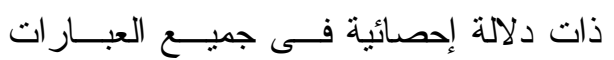

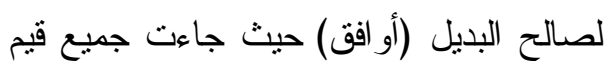
(كاب) دالة عند مستوى دلالة (1 ., ,.). أما من حيث ترتيب هذه العبارات بالنسسبة للأهمية النسبية لها فيلاحظ ما يأتى : جاءت العبارة (V) وهى (زيادة الجها لئل

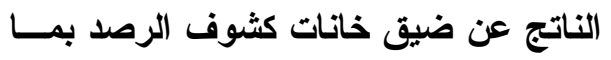

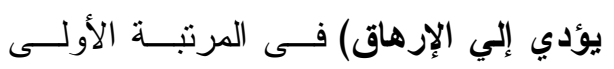

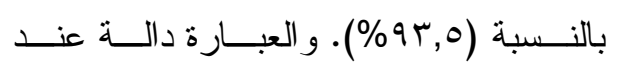
مستوي( ال. , ) ويري الباحث أن هذه النتيجة

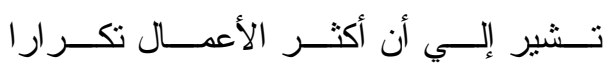

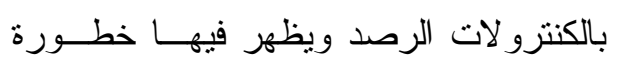
الفاقد الكمي بوضوح في ثلاثة جو انب الوقت

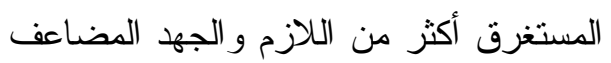

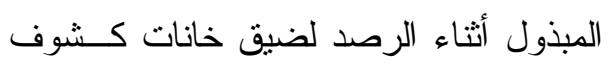
الرصد بالإضافة إلي كثوف الرصد نعاد إذا

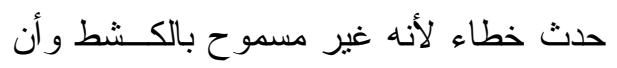
ضيق خانات كثوف الرصد أنها لا تتحمـل

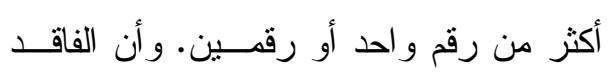
جزء كبير منه يعود علي أعضاء الكنترول. 
المطلوب تسليمها لشئون الطلبــة بــالإدارة التعليمية) فى المرتبة العاثــرة (الأخيــرة)

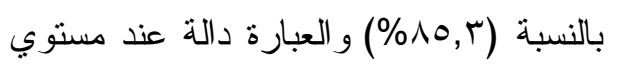
(1, (•) ويري الباحث أن هذه النتيجة تشير الي انه بعد ان سمح للمدارس بطباعة النتيجة

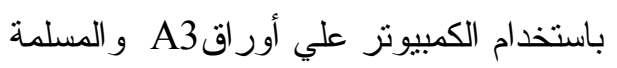
للإدار ات أصبح الفاقد يسيرًا. نتائج المحور الثاني: منطلبات الحــــ

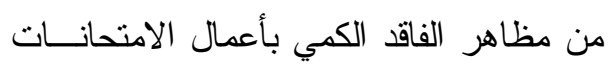

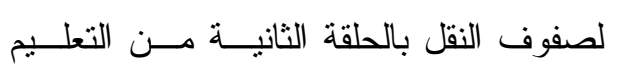
الأساسي لمعرفة رؤية عينــة الدراســـة مــن ماكن أعضاء ورؤساء الكنترو لات بالحلقة الثانيــة من التعليم الأساسي والبالغ عـدـدهم (rVO) مبحوث حول منطلبات الحد من مظاهر الفاقد

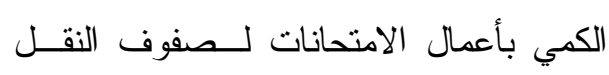

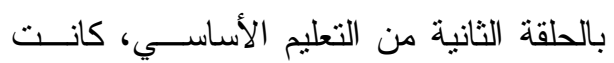

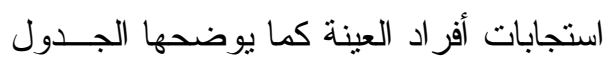
الآتي:
يؤدي الي نقص درجات الطالب لعدم وجود

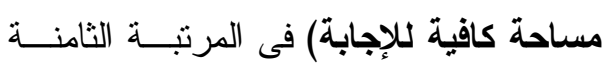

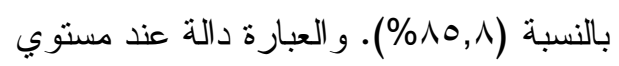
(1, (·) ويري الباحث أن هذه النتيجة تشير

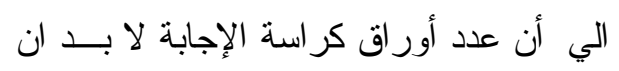

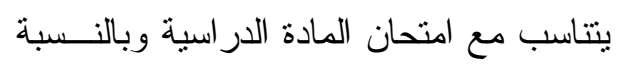

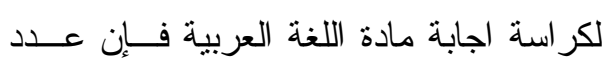
أور اق كر اسة الاجابة إذا كان بها نقص ينتج عنه تداخل اجابات الطالب وذللك يؤدي إلــي

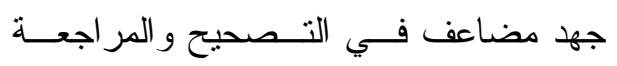
بالإضافة إلي فاقد في درجات الطالب. جاءت العبارة (ץ) وهى (زيادة عدد

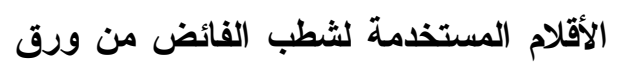

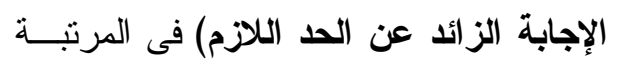

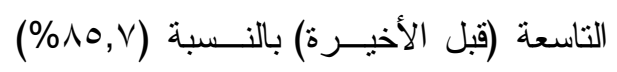

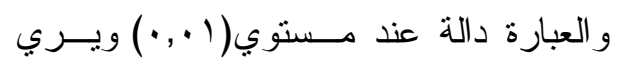
الباحث أن هذه النتيجة تشير إلي الزيادة فــي استهلاك الأقلام أقل مظهر من مظاهر الفاقد ويرجع ذلك الي ثن القلم المستخدم. جاءت العبارة (1) وهى (الزيادة في نَسَخ كثوف الرصد أكثر من مرة بالكنترول 
جدول (0)

استجابات عينة الار اسة حول متطلبات الحد من مظاهر الفاقد الكمي بأعمال الامتحانات لصفوف النقل

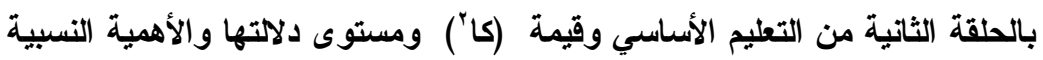

\begin{tabular}{|c|c|c|c|c|c|c|c|c|c|c|}
\hline \multirow{3}{*}{ 雪 } & \multirow{3}{*}{ 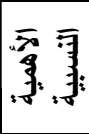 } & \multirow{3}{*}{ 矛 } & \multirow{3}{*}{ كاr } & \multicolumn{6}{|c|}{ البدائل } & \multirow{3}{*}{ العبارات } \\
\hline & & & & \multicolumn{2}{|c|}{ لا أو افق } & \multicolumn{2}{|c|}{ إلى حد ما } & \multicolumn{2}{|c|}{ أو افق } & \\
\hline & & & & $\%$ & ك5 & $\%$ & 5 & $\%$ & ك & \\
\hline$\wedge$ & 91,7 & $\cdot, \cdot 1$ & $r V T, 0$ & 0,1 & $1 \varepsilon$ & $1 \varepsilon, 9$ & \& & $\wedge \cdot, \cdot$ & rr. & 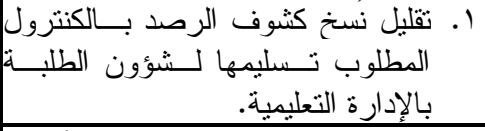 \\
\hline 7 & 94,0 & $\cdot, \cdot, 1$ & $r Y \varepsilon, V$ & $\varepsilon, \cdot$ & 11 & 11,7 & Tr & $\wedge \varepsilon, \varepsilon$ & Trt & 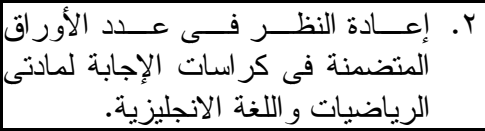 \\
\hline V & 94,0 & $\cdot, \cdot, 1$ & $r \wedge v, \wedge$ & $r, \tau$ & 1. & $10, r$ & $\varepsilon r$ & $\wedge 1,1$ & TrK & 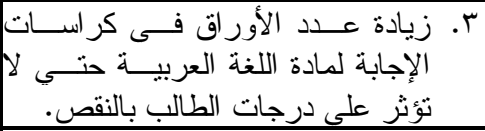 \\
\hline 1 & $9 \wedge, \wedge$ & $\cdot, \cdot, 1$ & $r r q, 0$ & . & . & $r, \tau$ & 1. & $97, \varepsilon$ & Y7o & 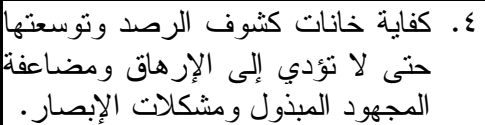 \\
\hline$r$ & $9 \vee, 7$ & $\cdot, \cdot, 1$ & $\leqslant \leqslant r, 0$ & $\cdot, \Sigma$ & 1 & 7,0 & 11 & 94,1 & rot & 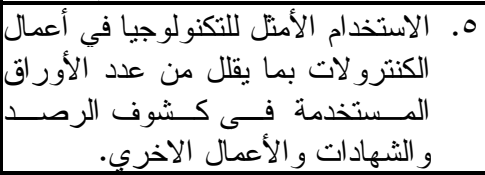 \\
\hline 0 & $90, \varepsilon$ & $\cdot, \cdot, 1$ & $\varepsilon \cdots, 1$ & $\varepsilon, \cdot$ & 11 & $0, \wedge$ & 17 & $q \cdot, r$ & $r \leqslant 1$ & 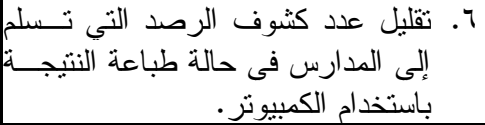 \\
\hline$\varepsilon$ & $q \vee, r$ & $\cdot, \cdot 1$ & $\varepsilon r v, q$ & $\cdot, \mathrm{V}$ & r & 7,0 & 11 & $q T, V$ & roo & 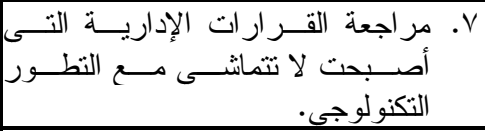 \\
\hline$r$ & $9 \vee, \wedge$ & $\cdot, \cdot, 1$ & $r \cdot V, V$ & . & . & 7,0 & 11 & 94,0 & rov & 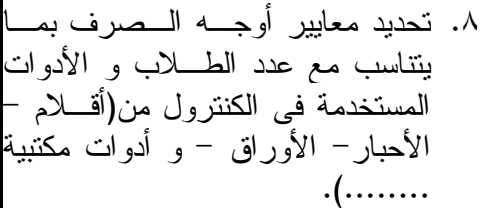 \\
\hline
\end{tabular}

يتضح من نتائج جدول (0) ما يأتى:

لصفوف النقل بالحلقة الثانيــة مــن التعلــيم الأساسي بأن هنالك فروقاً ذات دلالة إحصائية جاءت استجابات عينة الدراسة مـن

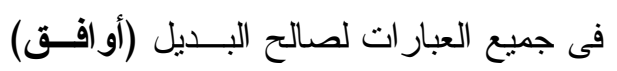
أعضاء ورؤساء الكنترو لات بالحلقة الثانيـــة

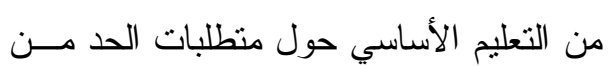

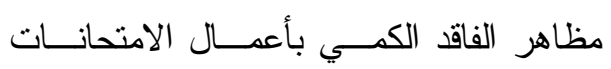


المدارس مخصصصاتها الماليـــة ويحيطهــــا

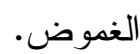

جاءت العبارة (0) وهى (الاســتخدام

الأمثل للتكنولوجيا في أعمال الكنترولات بما

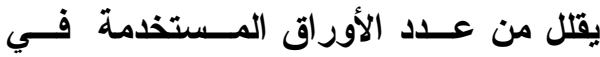

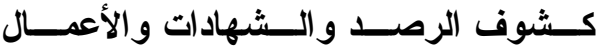

الاخــري) فــى المرتبـــة الثالثـــة بالنـسبية

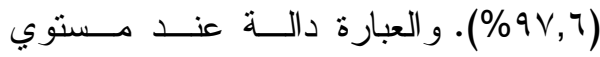

(1., (•) ويري الباحث ان هذه النتيجة نتير

الي محدودية توظيف التكنولوجيا في اعمــال

الامتحانات وبناء عليه لابد من توظيف امتل

و اشثل للتكنولوجيا في اعمال الامتحانات .

جاءت العبارة (r) وهى (إعادة النظر

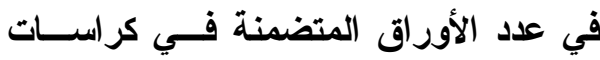
الإجابة لمادتي الرياضيات واللغة الاتجليزية)

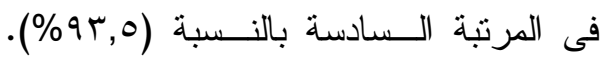
و العبارة دالة عند مستوي (1 .,. •) و العبـارة

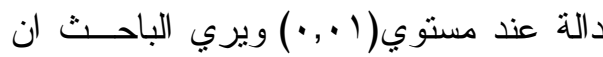
هذه النتيجة تشير الي انه لابد من اعادة تقييم

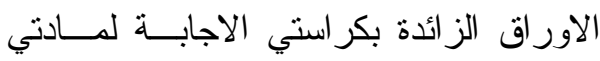

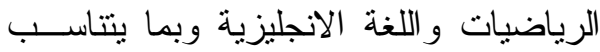
مع الورقة الامتحانية. جاءت العبارة (r)وهى (زيادة عدد

الأوراق في كراسات الإجابة لمــادة اللغــة العربية حتي لا تؤثر علي درجات الطالــب الاجب بالنقص) فى المرتبة السابعة (قبل الأخيــرة)

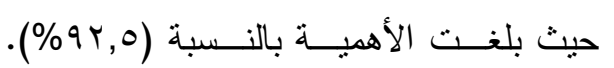

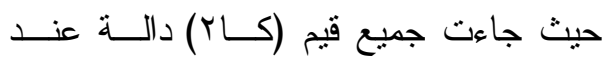
مستوى دلالة (1 +, (·). أما من حيث ترتيب هذه العبارات بالنسبة للأهمية النسبية لها فيلاحظ ما يأتى : جاءت العبــارة (ع) وهــى (كفايــة خانات كشوف الرصد وتوســتها حتــي لا لا تؤدي إلي الإرهــاق ومــــاعفة المجهـــود

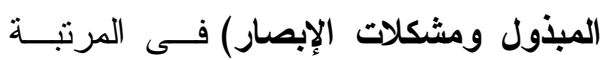

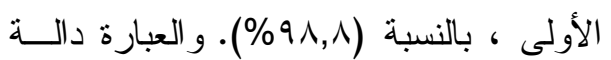

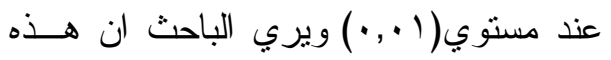

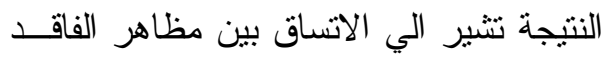

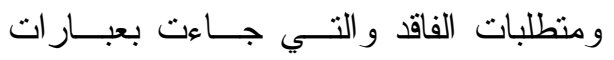
المحورين حيث ضيق خانات كثوف الرصد

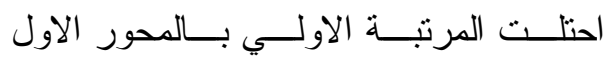

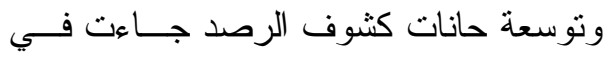
المرتبة الاولي بالمحور الثاني مما يدل علي اهميتها للحد من مظاهر الفاقد.

جاءت العبــارة (^) وهـى (تحديـــ

معاييز أوجه الصرف بما يتناسب مع عـداند الطلاب و الأدوات المستخدمة في الكنترول

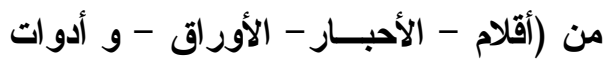
مكتبية ........) فى المرنبة الثانية بالنسبة

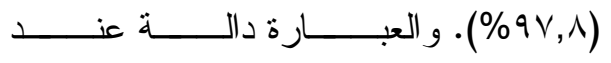
مستوي( ا ., •) ويري الباحث ان هذه النتيجة

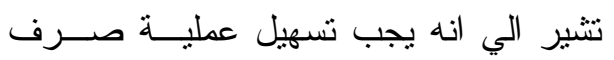

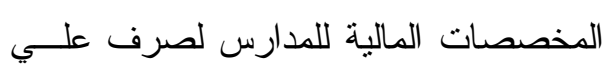

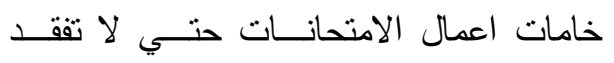




$$
\begin{aligned}
& \text { r- الاستخدام الأمثل للتكنولوجيا في أعمال } \\
& \text { و العبارة دالة عند مـستوي( ( , ••)ويــري } \\
& \text { الكنترو لات بما يقلل من عــدد الأوراق الاقين }
\end{aligned}
$$

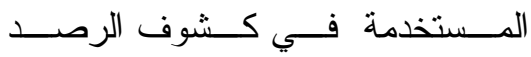

$$
\begin{aligned}
& \text { و الثهادات و الأعمال الاخري } \\
& \text { ع - مر اجعــة القــر ار ات الإداريــة التــي }
\end{aligned}
$$

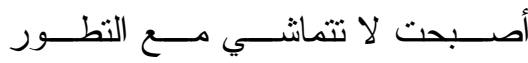

$$
\begin{aligned}
& \text { التكنولوجي. } \\
& \text { 0- تقليل عدد كشوف الرصد الني تسلم إلي }
\end{aligned}
$$

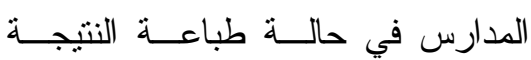

$$
\begin{aligned}
& \text { باستخدام الكمبيوتر . } \\
& \text { 7- إعادة النظر في عدد الأوراق المتضمنة } \\
& \text { في كراسات الإجابة لمادتي الرياضيات } \\
& \text { و اللغة الانجليزية } \\
& \text { V- زيادة عدد الأوراق في كر اسات الإجابة }
\end{aligned}
$$

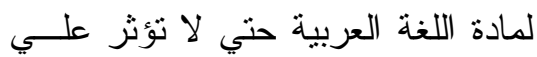

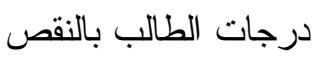

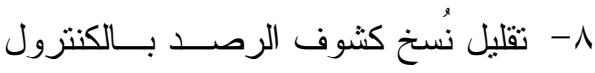

$$
\begin{aligned}
& \text { المطلـــوب تـــليمها لــشؤون الطلبــــة } \\
& \text { بالإدارة التعليمية } \\
& \text { 9- استخدام الوسائل التكنولوجية في اعمال }
\end{aligned}
$$

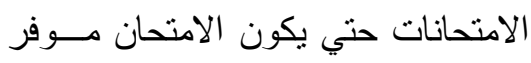

$$
\begin{aligned}
& \text { للوقت و الجهد و النفقات } \\
& \text { • } 1 \text { - يجب مراجعــة القـــرار ات الخاصـــة } \\
& \text { باعمال الامتحانات و اجر اءاتها وتعديلها } \\
& \text { حتي تساير التطور التكنولوجي } \\
& \text { 11- تفعيل دور المراكز ( مركز تطــــير } \\
& \text { الامتحانات و الثقـــويم الثربـــوي، المركز } \\
& \text { الباحث ان هذه النتيجة نثير الـــي ان اللغـــة } \\
& \text { العربية من المو اد التي تعتمد علــي الكتابـــة } \\
& \text { اكثر من المو اد الاخري. } \\
& \text { جاءت العبارة (1) وهى (تقليل نُسخ } \\
& \text { كثوف الرصد بالكنترول المطلوب تسليمها } \\
& \text { لثؤون الطلبة بالإدارة التعليمية) فى المرتبة }
\end{aligned}
$$

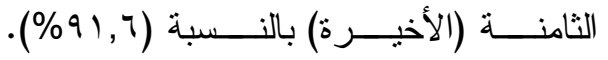

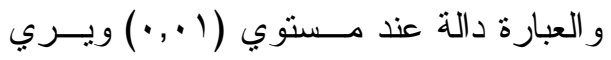

$$
\begin{aligned}
& \text { الباحث ان هذه النتيجة تشير الي ان خطورة } \\
& \text { الفاقد محدودة لذا جاءت في المرنبة الاخيرة. } \\
& \text { و انه يجب ايجاد طريقة لتقليل نسخ كـشـوف لنش } \\
& \text { الرصد المطلوب نسليمها الي شُئون الطلبة. }
\end{aligned}
$$

\section{توصيات البحث}

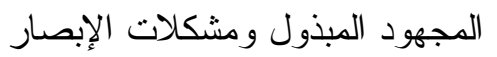

$$
\begin{aligned}
& \text { r- تحديد معايير أوجه الصرف بما يتتاسب } \\
& \text { مع عدد الطلاب و الأدوات المستخدمة }
\end{aligned}
$$

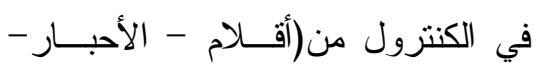

$$
\begin{aligned}
& \text { الأور اق - و أدو ات مكنبية .........) }
\end{aligned}
$$


11 - الاهتمــــام بالامتحانــــات وبخاصـــــة

الامتحانات العملية التي تقيس الجانــب

المهاري و عدم تغيير طبيعتها

9 19- التخلــي تــدريجيا عـن الامتحانــات

التقليدية في عمليــة القبــاس واتبـــاع

الاساليب الحديثة و التفاعل معها

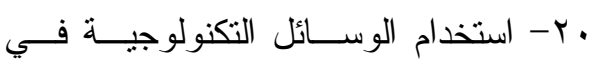

اعمال الامتحانات حتي يكون الامتحان

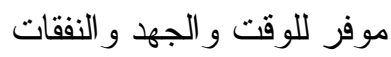

أولا : المراجع العربية :

القـــواميس و اللـــوائح و والقـــوانين

$$
\text { والتقريز }
$$

(1) مجمع اللغة العربية 1999: المعجم

الوجيز ، القاهرة ، الهيئة العامة لشئون

$$
\text { المطابع الاميرية. }
$$

جمهورية مـــر العربيــة رئاســـة

الوزر اء (11)

لضمان جودة التعليم و الإعتماد القرير

التحليلي لاداء مؤسسات التعليم قبــلـ

الجامعي في ضوء زيار ات الاعتماد،

$$
\text { القاهرة) }
$$

(ب) البنك الــدولي / الاتحـــاد الأوروبــي

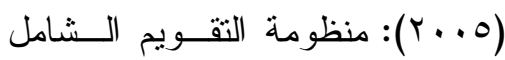

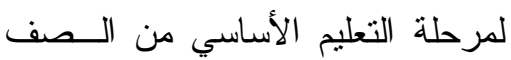

الأول إلي الصف الخامس الإبتــدائي

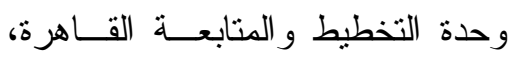

القومي للامتحانات المجلـس الاعلــي

للامتحانات و التقويم التزبوي ، المركز

القومي للبحوث التربوية و التتمية، بنوك

الاسئلة) و التي تتولي شئون الامتحانات

$$
\text { و اعمالها }
$$

r ا - تخفيف العبء علي القائمين باعمــال

الامتحانات و الناتج من كثرة الاعمــال

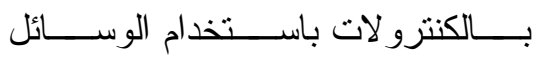

التكنولوجية في الرصد وطباعة كثوف الرصد و الثهادات و اعلان النتيجة

سا - در اسة المـستوي الكمــي و الكيفـي

لاوراق الاجايـــة و الخامـــات الورقيـــة المستخدمة في اعمال الكنتزولات

ع ا- التخلــي تــدريجيا عـن الامتحانــات

التقليدية في عمليــة القيــاس و اتبــــاع الاساليب الحديثة و التفاعل معها

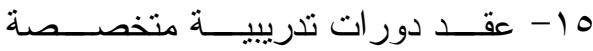

للقائمين علي اعمال الامتحانات تـشمل

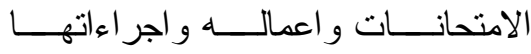

$$
\text { و اعمالها }
$$

17 - عقد عقد دورات تدريبية متخصــصة للمعلمين في مجال الامتحانات و التقويم و الاهتمام بهذه الامتحانات مــن حيـــث

$$
\text { الكم و الكيف }
$$

IV - ضرورة ان بكون الامتحان اقتـصاديا

$$
\text { في الوقت و الجهد و المال }
$$




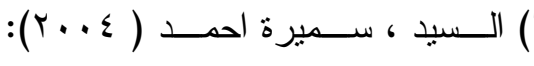

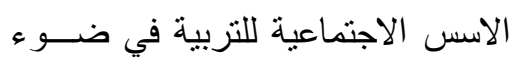

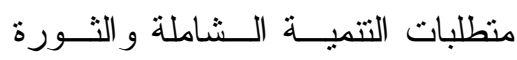

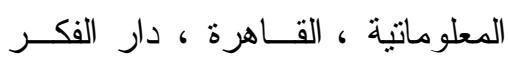

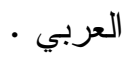

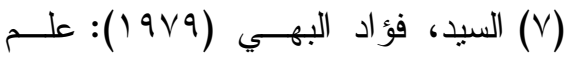

$$
\begin{aligned}
& \text { الـــفس الاحــصائي وقيـــس العقــل } \\
& \text { البشري(القاهر : دار الفكر العربي، ط }
\end{aligned}
$$

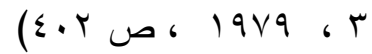

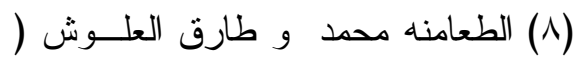

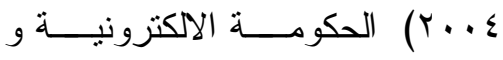

$$
\begin{aligned}
& \text { تطبيقاتها في الوطن العربي ، القاهرة } \\
& \text { : المنظمة العربية للتتمية الادارية . } \\
& \text { (9) العجمي، محمد ( § . ז) : منطلبات }
\end{aligned}
$$

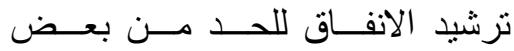

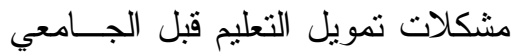

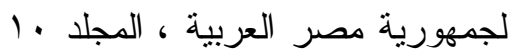

$$
\begin{aligned}
& \text { ، }
\end{aligned}
$$

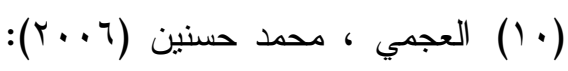

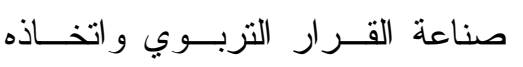

$$
\begin{aligned}
& \text { النظرية-النموذج ( الإسكندرية ، دار }
\end{aligned}
$$

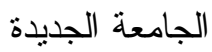

$$
\begin{aligned}
& \text { (Y) (Y) عطيفة، حمدي ابو الفنوح (Y. (Y): } \\
& \text { منهجية البحث العلمي وتطبيقاتها فـي الـي } \\
& \text { الدر اسات التريوية و النفسية القــاهرة: }
\end{aligned}
$$

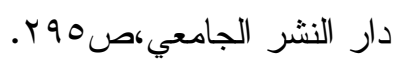

$$
\begin{aligned}
& \text { صع } \\
& \text { وز وزارة التزبيــة و التعــــيم : القــــرار }
\end{aligned}
$$

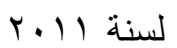

$$
\begin{aligned}
& \text { الكتب }
\end{aligned}
$$

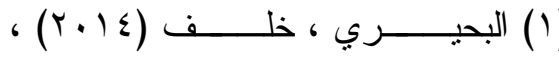

$$
\begin{aligned}
& \text { اقتصـاديات التعلــيم ، القــاهرة : دار } \\
& \text { الفجر للنشر و النتوزيع } \\
& \text { (Y) البياتي، محمــود مهـدي (ب. (ب): } \\
& \text { تحليل البيانات الاحــصائية بـستخدام } \\
& \text { البرنامج الاحصائي ssps (عمان: دار }
\end{aligned}
$$

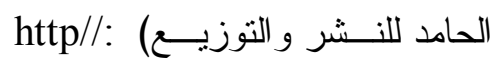

$$
\begin{aligned}
& \text { www.mohyssin.com/forum } \\
& \text { Available at10/10/2011 } \\
& \text { (r) جادالمولي ، ايمان محمد ، إبر اهيم ، (r) }
\end{aligned}
$$

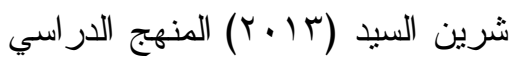

$$
\begin{aligned}
& \text { المعايير وتحقيق الجودة. المنصورة ، }
\end{aligned}
$$

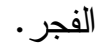

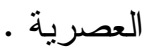

$$
\begin{aligned}
& \text { طا ، دار الكتاب الحديث) وله وله }
\end{aligned}
$$


معايير الجود الــشاملة" مجلـــة كليــة

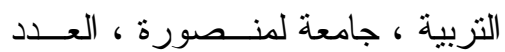

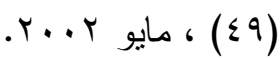

المخلافي ، محمـــــــــــان خالــــ

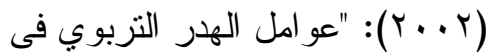

التعليم الجامعي كما بتصور ها الطلبة

في كليات التزبية، جامعة صـــنعاء"،

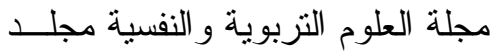

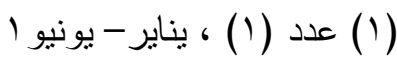

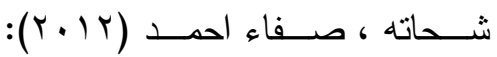

أسس تقييم أداء المتعلم وقياس فاعلية المؤسسة التعليمية (مدخل تقييم القيمة المضافة) جامعة الأمــــار ات العربيـــة لهونة

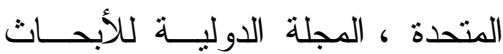

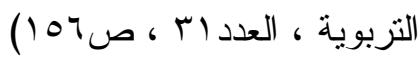

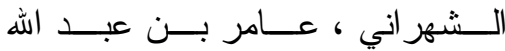

(Y. . V )

بعض كليات جامعة الملك خالد خلال

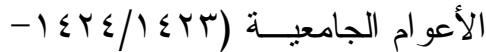

דr \&

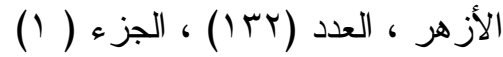

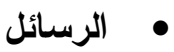

(1) الخولى ، إيمان عبــــ عبــد الحــافظ

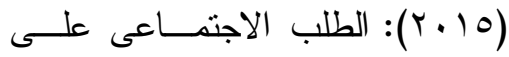

أنماط التعليم الأساسـى و انعكاســاته التهـ

على تكافؤ الفرص التعليمية ،رسالة

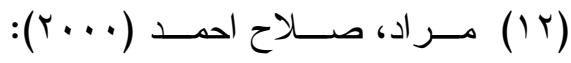

الاساليب الاحصائية في العلوم النفسية

و النزبوية والاجتماعية، القاهرة مكتبة

$$
\text { الانجلو المصرية. }
$$

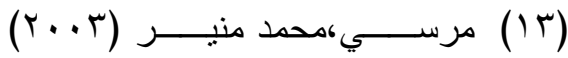

:البحث التربــوي وكيـف نفهمـــهـ

القاهرة ،عالم الكتب،صول V7 ل .

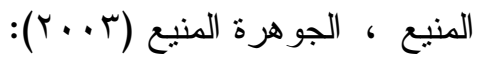

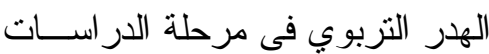

العليا بكليات البنات التابعــة لـــوز ارة لــات

Available at : التربية و التعليم. http//: www.mohyssin .com /forum 10/10/2011

(10) ميخائيل، إمطــانيوس ( (199V) :

القياس و التقويم في التزبية الحديثـــة ،

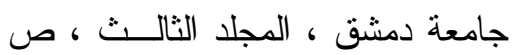

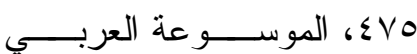
http://arabency.com.sy/detail/552

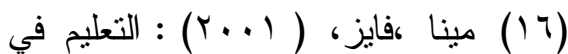

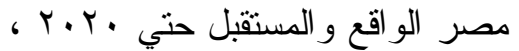

القاهرة، مكتبة الاتجلو المصرية.

$$
\text { • المجلات والدوريات }
$$

(1) حربي ، منير عبـــ الله ، رزق ، و

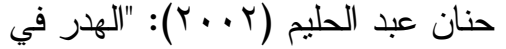

شعبة إعداد المعلم التجــاري بكليـــة

التزبية جامعة طنطا في ضوء بعض 
و التسرب و الإحجام بمرحلـــة التعلــيم

الأساسي في محافظة القاهرة ( دراسة

$$
\text { حالة) ، ص بrr) }
$$

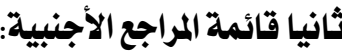

(1) Ericvaldman , Swanson: Achievement and wastage: An econometric analysis of the retention of basic skills in a developing country

\section{Dissertation}

Abstract

International

state

university of New York at Buffalo, 1988

(2) Gardner, SuanK: Student and faculty attributions of attrition in high and low - completing doctoral programs in the United States, SpringScience,Busines Media, University of Maine, Available At http://www. SpringScience 18/12/2012

(3) Jill, Johnes: Determinants of Student Wastage in Higher Education Journal Articles (080) Vol., No. 1, 1990, pp 87- 99.

(4) Loxely, W: Wastage in education: the international Encyclopedia of education research and studies, Vol. (9), Paris, 1995

$$
\begin{aligned}
& \text { ماجسنير غير منشورة ، كلية التربية } \\
& \text { ، جامعة المنصورة. } \\
& \text { (Y) الدياســـي ، مــروة بكــر مختــار } \\
& \text { (ז (ץ): منطلبات الحد من الهـر }
\end{aligned}
$$

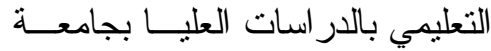

$$
\begin{aligned}
& \text { المنصورة ، رسالة ماجسستير غيــر }
\end{aligned}
$$

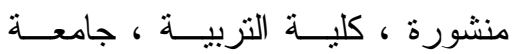

$$
\begin{aligned}
& \text { المنصورة، } \\
& \text { (r) القطري ، محمــود علــي محمــود }
\end{aligned}
$$

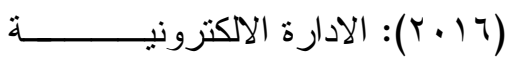

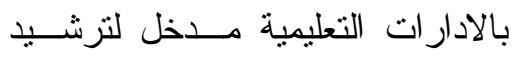

$$
\begin{aligned}
& \text { الانفاق التعليمي رسالة ماجسنير غير }
\end{aligned}
$$

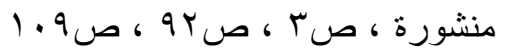

$$
\begin{aligned}
& \text { (§) عبد المقصود ، علاء احمد (10 ب): } \\
& \text { "متطلبات مو اجهة بعض عو امل الهدر" } \\
& \text { في التعليم الصناعي ، رسالة ماجستير } \\
& \text { غير منشورة ،كلية التزبيــة ،جامعسـة فيسة } \\
& \text { المنصورة. }
\end{aligned}
$$

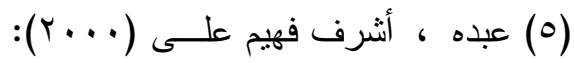

$$
\begin{aligned}
& \text { الفاقد الكمي وعواملــه فــي التعلــيم } \\
& \text { الجامعي المصري ، رسالة ماجسنير } \\
& \text { غير منشورة، كلية التربية ، جامعــة } \\
& \text { المنوفية. } \\
& \text { المركز القــومي للبحــوث التربويـــة }
\end{aligned}
$$

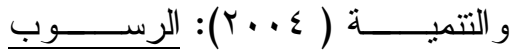

